\title{
Salvageable food losses from Vermont farms
}

\author{
Roni A. Neff a* \\ Elana K. D ean b \\ Research Consultant, Salvation Farms
}

Johns Hopkins Bloomberg School of Public Health

Marie L. Spiker c

Johns Hopkins Bloomberg School of Public Health

Theresa Snow d

Salvation Farms

Submitted September 12, 2017/ Revised January 9, February 8, and February 17, 2018 / Accepted February 19, 2018 /

Published online May 24, 2018 / Updated (D ean affiliation) May 27, 2018; updated June 15, 2018 (gleaning organizations)

Citation: Neff, R. A., D ean, E. K., Spiker, M. L., \& Snow, T. (2018). Salvageable food losses from

Vermont farms. Journal of A griculture, F ood Systems, and C ommunity D evelopment, 8(2), 39- 72.

https:/ / doi.org/ 10.5304/ jafscd.2018.082.006

Copyright (@) 2018 by the Authors. Published by the Lyson Center for Civic Agriculture and Food Systems. Open access under CC BY license.

\begin{abstract}
For a variety of reasons, farms cannot sell or donate all the food they produce, and some food crops are lost from the food supply. Food lost at the farm level represents a substantial environmental, economic, and nutritional cost to the food system. Few studies have estimated amounts of

a * Corresponding author: Roni A. Neff, D epartment of Environmental Health and Engineering and Center for a Livable Future, Johns Hopkins Bloomberg School of Public Health; 615 North Wolfe Street, Room W7010; Baltimore, MD 21205 USA; +1-410-614-6027; rneff1@jhu.edu

b Elana K. D ean, Research Consultant, Salvation Farms; EKD Monitoring \& Evaluation; 1324 Massachusetts Ave. SE \#1; Washington, DC 20003 USA; +1-508-736-6519; elana.k.dean@gmail.com

c Marie L. Spiker, D epartment of International Health, Johns Hopkins Bloomberg School of Public Health; 615 North Wolfe Street, W2513; Baltimore, MD 21205 USA; +1-410 223-1811; spiker@jhu.edu
\end{abstract}

food lost at the farm level in the U.S. We present a survey-based method for estimating crop loss quantities based on four estimates by farmers: percent available crops that are harvested, percent unharvested crops they would consider edible, percent harvested produce sold, and percent harvested produce donated. We applied the

d Theresa Snow, Salvation Farms; 49 Portland Street; Morrisville, VT 05661 USA; +1-802-888-4360; theresa@salvationfarms.org

\section{Author Note}

This research was based in part on an organizational report published online by Salvation Farms.

\section{Funding Disclosure}

The time of Roni Neff was supported by the Johns Hopkins Center for a Livable Future (CLF) with a gift from the G race Communications Foundation. Marie Spiker was supported by the CLF-Lerner Fellowship. The G race Communications Foundation had no role in study design, data collection, and analysis, decision to publish, or preparation of the manuscript. 
method in an online survey administered to 58 Vermont vegetable and berry farms. Within the sample, an estimated 16\% of vegetables and 15\% of berries were considered lost but salvageable in 2015. If these farms are representative of farms across the state, this would amount to approximately $13,684,000 \mathrm{lbs}$. $(6,207,000 \mathrm{~kg})$ of salvageable vegetables and $589,000 \mathrm{lbs}$. $(267,000 \mathrm{~kg})$ of salvageable berries. This lost produce contains substantial nutrients. For example, the amount of lost fiber is equivalent to the gap between actual and recommended fiber intake for 36,000 adult U.S. women. Most estimates are based on recall. While many farmers reported keeping records of crops harvested $(67 \%)$ and sold (69\%), few had records of other quantities needed for tracking losses. Sixty percent of farmers expressed interest in a state program that would compensate farmers for donations and nearly half expressed interest in one or more strategies to involve community groups in reducing losses. While not all produce that is lost can realistically be provided to consumers in a timely and cost-effective manner, this research highlights a high magnitude of loss and potentially, a considerable nutritional and economic opportunity. Further research is needed to confirm and add depth to these estimates and to evaluate potential solutions.

\section{Keywords}

Berry Production; Food Loss; Food Waste; Imperfect Produce; Quantification; Small Farms; Survey; Vegetable Production

\section{Introduction and Literature Review}

Farmers in Vermont harvested approximately 3,897 acres (1,577 hectares) of vegetables and 601 acres (243 ha) of berries in 2012 (U.S. D epartment of Agriculture National Agricultural Statistics Service [USD A NASS], 2012a, 2012b). An unknown but substantial portion of the edible product is lost at the farm level. The Food and Agriculture O rganization of the United Nations (FAO) estimates that about $42 \%$ of the overall food supply in North America and $O$ ceania goes to waste, with about 33\% of that waste occurring at the farm level (G ustavsson, Cederberg, Sonesson, \& Emanuelsson, 2013; FAO, 2011). The FAO's estimate represents one of only a few attempts to quantify farm-level food losses in the U.S. The USD A does not collect such data. Additionally, only a few studies have elaborated the nature and determinants of food losses on farms in highincome countries like the U.S. (Berkenkamp, 2016; Davis et al., 2011).

The International Food Loss and Waste Accounting and Reporting Standard (FLW Standard) defines food loss and waste (FLW) as "food and/ or associated inedible parts removed from the food supply chain," and uses the terms, "loss" and "waste" interchangeably (World Resources Institute, 2016). We use these definitions and further distinguish "salvageable food loss" as food removed from the food supply chain while still edible. Salvageable food loss includes products indistinguishable from those sold in stores as well as high quality, edible products with cosmetic imperfections such as nonstandard sizes and/ or shapes or blemishes. We do not include donated food in our definition of FLW since it remains in the supply chain for human consumption and is thus not considered wasted.

Farm-level FLW represents: a substantial loss of income for food producers, waste of the resource inputs used to produce the food, and loss of nutritious food for consumers. Even when crops are turned under or composted on the farm to nourish the soil, the result is high-input compost that relied on considerable water, energy, labor, and manufactured inputs such as fertilizers. Lowerinput methods and inedible organic material can be used to produce compost instead.

As we will describe, we identified only three prior assessments of multi-crop farm-level losses in the U.S.; Minnesota estimates of produce imperfection rates; British retailer rejections of produce for aesthetic and other reasons; and interviews with California growers and produce packers (FAO, 2011; Milepost Consulting, 2012; ReFED , 2016). Q uantifying on-farm losses and assessing reasons is essential for identifying and prioritizing response strategies and interventions, including exploring the amount of loss considered acceptable given realistic tradeoffs and costs involved in food recovery. D ata can also 
strengthen stakeholder motivation to address the problem, including building support for investment in infrastructure and programs. It is also beneficial for food donation programs to gain further insight into the extent of food that could become available with effective interventions. Lastly, the U.S. has committed to halving waste of food by 2030 (U.S. Environmental Protection Agency [U.S. EPA], n.d.-a), and without baseline or other data on farmlevel FLW, it is impossible to track progress toward that goal or to evaluate intervention impacts. Further assessments are greatly needed, covering diverse geographies, crops, and farm sizes, and using diverse methodologies.

Waste of fruits and vegetables leads to vast losses of under-consumed nutrients including, for example, enough calcium for 680.3 million adults

Figure 1. Vermont Counties

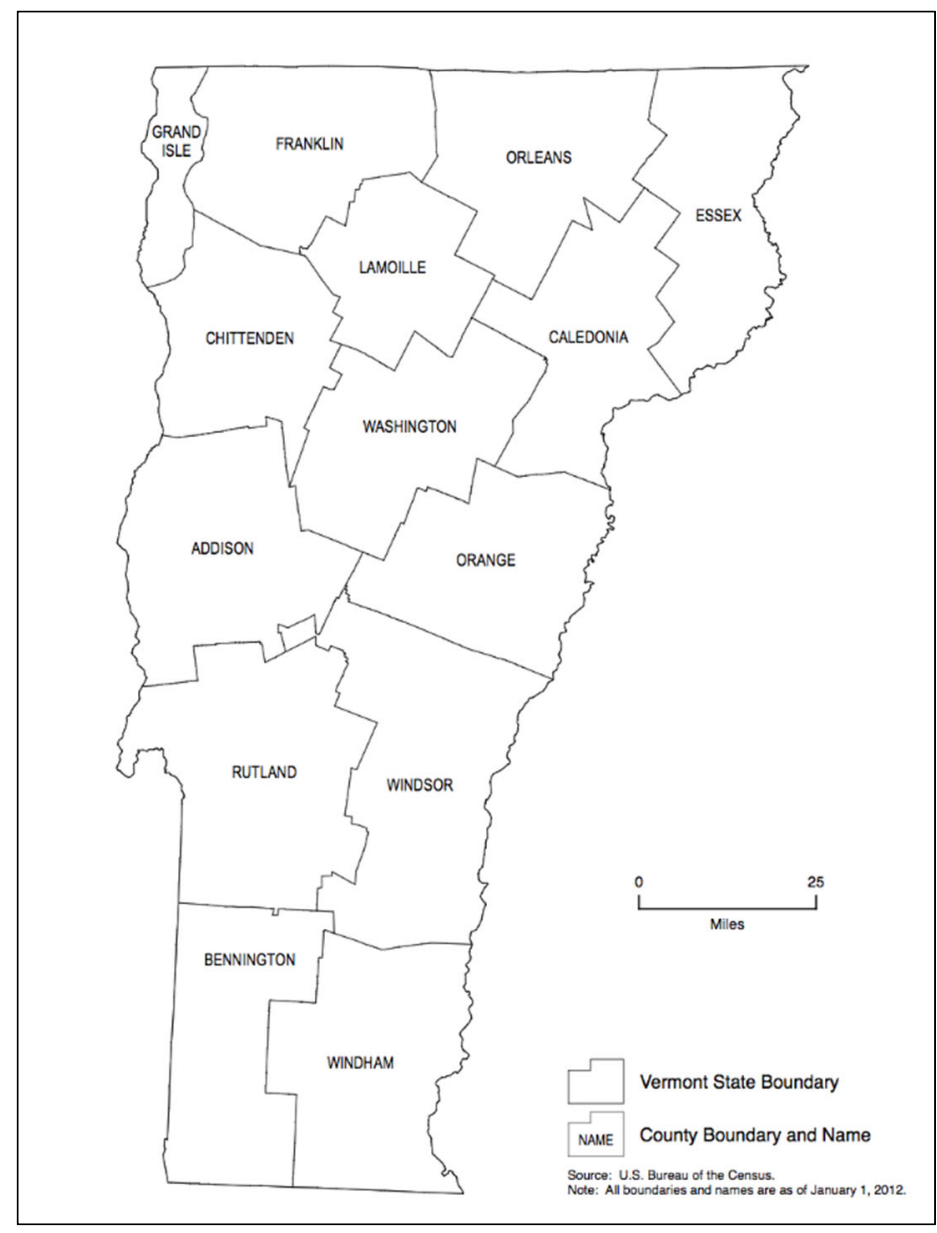

Source: USDA National Agricultural Statistics Service, 2012b. and enough fiber across the U.S. to fill the gap between actual and recommended consumption of fiber for 206.6 million adults (Spiker, Hiza, Siddiqi, $\&$ Neff, 2017). In Vermont, an estimated 74,600 individuals (11.9\% of the population) were food insecure in 2015 (Feeding America, 2017). Studies commonly associate food insecurity with reduced intake of fruits and vegetables (Hanson \& Connor, 2014); therefore, strengthened food recovery could enable increased consumption among those in need.

This study provides the first empirical data on farm-level food loss in New England, and among the first farm-level data on the topic nationally. Salvation Farms, a Vermont nonprofit focused on "fostering collaborative, cross-sector partnerships that create efficient management practices for Vermont's farm surplus," initiated and led the project. This manuscript builds on the August 2016 report, F ood L oss in V ermont: E stimating A nnual V egetable \& B erry L oss. A Salvation Farm's A nalysis (Snow \& D ean, 2016) by providing further literature review and analysis.

Vermont farms are often small and mid-sized, and products are often marketed directly, rather than sold into national markets, meaning the findings from this analysis may have particular value to other states with a preponderance of small farms. Figure 1 depicts the state and its counties.

We developed and administered the Vermont Food Loss Survey in spring 2016, with the aim of estimating the quantity of farm-level FLW among sampled farms, aggregating the estimates to the state level in Vermont, and learning from farmer perspectives on this waste. The research focused on vegetable and berry farms because fruits and vegetables combined are the most frequently wasted agricultural product type and because they are both perishable and nutritious (Buzby, FarahWells, \& Hyman, 2014).

\section{Applied Research Methods}

Our research methods reflect the steps identified in the International FLW 
standard, which provides an internationally consistent approach to measurement (World Resources Institute, 2016). The standard was finalized after our data collection was completed, but we reviewed draft versions during development. While the FLW Standard does not cover pre-harvest losses, we extend the approach to include these, given their centrality in understanding farm-level waste.

The FLW Standard includes the following steps: (1) define goals; (2) review accounting and reporting principles; (3) establish scope; (4) decide how to quantify FLW; (5) gather and analyze data; (6) calculate inventory results; (7) assess uncertainty; and (8) report FLW inventory. Table 1 presents our approaches to these steps.
Survey Instrument

We designed the survey instrument based on our research questions, taking into consideration feedback from farmer participants in focus groups and pre-survey interviews, and from experts in wasted food, Vermont agriculture, and survey methods. (See Appendix A for the full instrument.)

Part 1: We began by asking farmers about farm size, specific crops grown and quantities planted and harvested. To estimate the percent of crops lost, we then asked farmers to estimate the following:

Q 1: What percent of the vegetables and/ or fruits, berries \& nuts [henceforth crops]

Table 1. Research Approach in Context of the Requirements in the Food Loss and Waste Standarda

\begin{tabular}{|c|c|}
\hline FLW Standard Step & Our Approach \\
\hline Define goals & $\begin{array}{l}\text { To quantify FLW in order to contribute to advancing food recovery in Vermont and build an } \\
\text { understanding of farm-level FLW in the U.S. }\end{array}$ \\
\hline $\begin{array}{l}\text { Review accounting and } \\
\text { reporting principles }\end{array}$ & $\begin{array}{l}\text { To the extent feasible, our research adheres to the accounting and reporting principles: } \\
\text { relevance, completeness, consistency, transparency, and accuracy. Limitations are } \\
\text { considered in the Discussion section. }\end{array}$ \\
\hline \multirow[t]{4}{*}{ Establish scope } & Timeframe: 2015 growing season. \\
\hline & $\begin{array}{l}\text { Material type: Edible vegetables and berries, as defined by farmers. For some parts of the } \\
\text { analysis, we used data from the Vermont agricultural census, which includes melons in the } \\
\text { vegetables category. }\end{array}$ \\
\hline & $\begin{array}{l}\text { Destination: We collected survey data to identify destinations of lost crops, but the research } \\
\text { did not assess percent of crops going to each destination, and we did not assess the extent } \\
\text { of valorization. }\end{array}$ \\
\hline & $\begin{array}{l}\text { Boundaries: } \\
\text { - Food category, United Nations Central Product Classification (United Nations, 2015): } \\
\text { vegetables }(012) \text {, edible roots and tubers }(015) \text { and berries }(0135) ; \\
\text { - Lifecycle stage, United Nations Standard Industrial Classification of All Activities (United } \\
\text { Nations, Department of Economic and Social Affairs, \& Statistics Division, 2008): Growing } \\
\text { of vegetables and melons, roots and tubers }(0113) ; \text { Growing of other tree and bush fruits } \\
\text { and nuts (0125). } \\
\text { - Geography: U.S. state of Vermont. } \\
\text { - Organization: We surveyed a sample of farms, and extrapolated results to create } \\
\text { statewide estimates. }\end{array}$ \\
\hline Decide how to quantify FLW & Described below in Methods \\
\hline Gather and analyze data & Described below in Methods \\
\hline Calculate inventory results & Described below in Methods \\
\hline Assess uncertainty & $\begin{array}{l}\text { We performed sensitivity analyses to assess possible impacts of differing crop yield } \\
\text { percentages and differing amounts of the salvageable loss being redirected to human } \\
\text { consumption }\end{array}$ \\
\hline Report FLW inventory & Described below in Results \\
\hline
\end{tabular}

a World Resources Institute, 2016. 
that grew on those [planted] acres did you harvest?

Q2: What percent of the crops left in the field (i.e., that you did not harvest) were edible?

Q3: What percent of the crops that you harvested did you sell?

Q4: What percent of the crops that you did not sell did you donate?

These questions were selected due to focus group and interview input from farmers regarding what they would reasonably be able to estimate. It is recognized that many of the estimates were based on recall and all are self-reported, potentially leading to limitations in results. However, no other data sources were available at this time.

Part 2: Farmers had the option to participate in additional questions adding depth and context, including listing their three main crops and answering questions about the following:

- Reasons for not harvesting and not selling produce

- The fate of unharvested and unsold items

- Quantities lost during washing, packing, storing, transporting, and at market

- Types of sales venues

- Recordkeeping about planting, harvesting, sales, and losses

- Types and quality of services provided by community groups to the farm, and types of services desired

- Past and planned claims for federal tax deductions for food donations, and level of interest in state-provided financial compensation for farmers for food donations

\section{Survey Sampling}

We surveyed farmers online via a Q ualtrics survey from A pril 5-25, 2016. All Vermont farms were eligible to participate if they grew vegetables $(n=789)$ and/ or fruit. We received few responses from growers of fruits other than berries, so we limited the analysis to berries ( $n=535$ in state). Some farms grew both vegetables and berries
(USD A National Agricultural Statistics Service, 2012a).

We performed broad outreach and sent follow-up reminders, including through the email lists of Salvation Farms, the Vermont Vegetable and Berry Growers Association, and Vermont Farm to Plate. It is unknown how many farmers received invitations or duplicate requests. O utreach materials indicated that the survey would help Salvation Farms estimate the amount of food loss farmers were experiencing and understand more about the issue from their perspectives. We entered participants in survey Part 1 into a raffle for a US $\$ 100$ gift certificate, and those in Part 2 for a US\$300 gift certificate. We assured participants that only aggregated responses would be reported.

$D$ ata $A$ nalysis

In addition to performing descriptive analyses of the survey responses, we calculated estimated pounds of salvageable food loss as follows. First, we multiplied provided data on acres harvested by published yield fractions. Specifically, we used the fractions: 0.5 pounds $(0.23 \mathrm{~kg})$ of vegetables per square foot, developed by the Rutgers New Jersey Agricultural Experiment Station for small-scale farms that grow a large variety of vegetables, much like the typical Vermont vegetable farm; and 0.15 pounds $(0.07 \mathrm{~kg})$ of berries harvested per square foot, an estimate obtained from averaging the expected yields for strawberries, blueberries, and raspberries for New England (G rubinger, 2013; Rabin, Zinati, \& Nitzsche, 2012). While obtaining information about each farm's yield estimates rather than using these published numbers would improve specificity, it could also add considerably to subject burden, decrease consistency, and add another source of uncertainty if their estimates were not effective. We chose to use the Rutgers estimate for vegetables, rather than available Vermont-specific yield estimates for 42 vegetable crops, because we did not have acreage data for all of those crops to enable determining how best to derive a single yield fraction from them. A sensitivity analysis was performed using a simple average of those estimates.

We then, as shown in Figure 2, used average survey responses for Q1 (percent of crop 
Figure 2. Schematic of Method Applying Survey Responses to Estimate Salvageable Loss

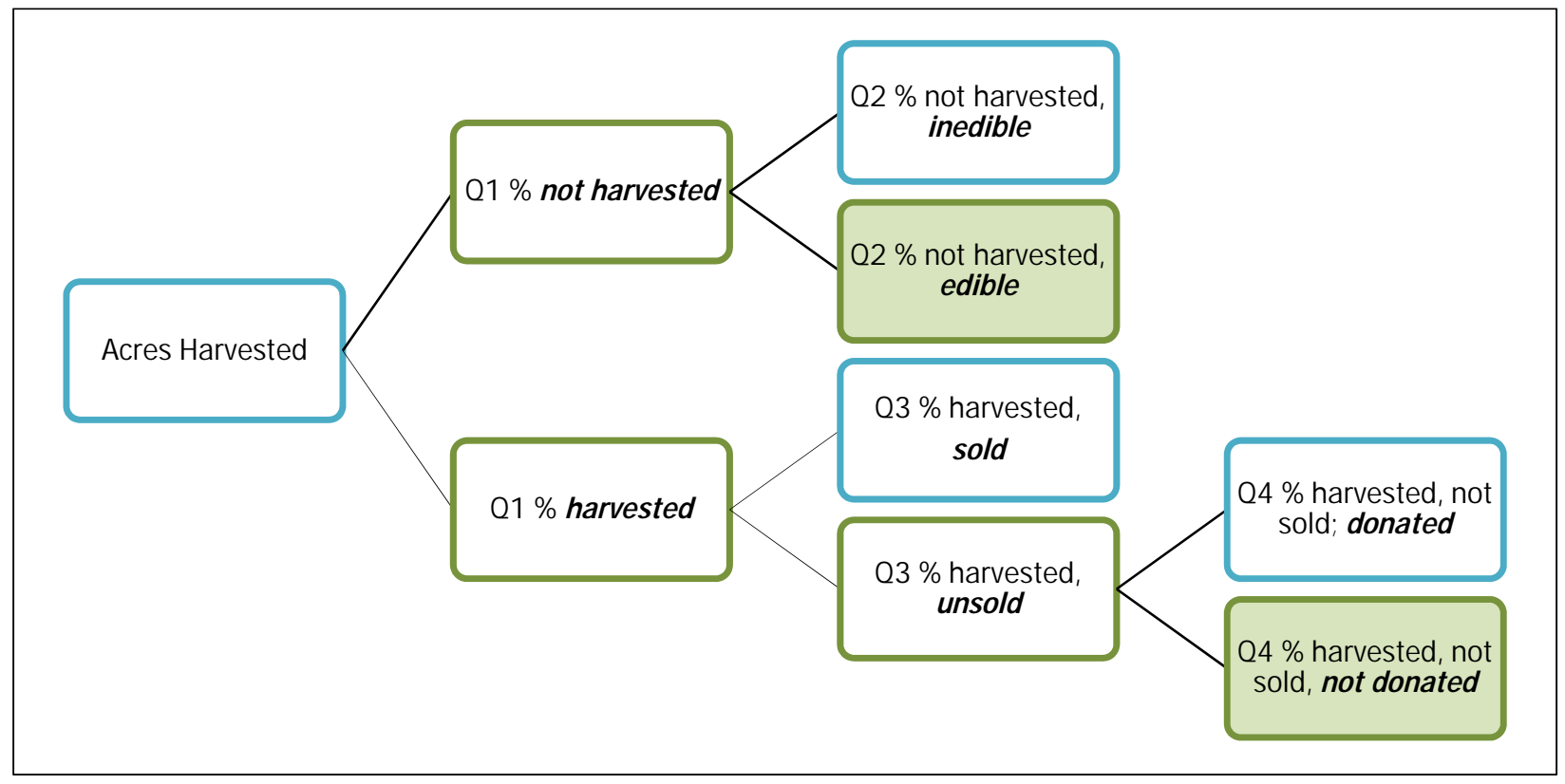

harvested) and census acres available for harvest, to segment the projected harvest into harvested and unharvested. For the unharvested produce, we applied the percent from Q2 to segment into edible and inedible, recognizing that respondent perceptions may differ. For the harvested produce, we applied the percent from Q 3 to divide into sold and unsold. Unsold produce was then divided into donated and not donated using the percent from Q4. Salvageable food loss was calculated as the sum of food that was unharvested but edible, and food that was harvested but not sold or donated (see shaded boxes in Figure 2). In other words, salvageable food loss consists of edible food that could be sold to consumers or donated to community organizations, but that is currently lost. The data are depicted in Sankey diagrams in addition to tabular form. We supplemented the presentation of the mean findings with the $25^{\text {th }}, 50^{\text {th }}$, and $75^{\text {th }}$ percentile estimates based on individual responses in order to provide context for the extent of variation in the data.

O ur next step was to extrapolate the sample estimates to the state level. We used 2012 Agricultural Census data on acres of vegetables and berries harvested in the state and applied the above yield fractions to estimate the total expected yield. Then we applied the farmer estimates of percent harvested, edible, sold and donated to these amounts.

We performed sensitivity analyses including applying diverse crop yield percentages and subtracting conservative estimates of "lost" food that may have actually been gleaned, eaten directly or processed into value-added crops. Lastly, we estimated vegetable and berry loss by county by applying statewide loss rates to acres planted by county (USD A National Agricultural Statistics Service, 2012b).

Lastly, we provide a descriptive overview of reported record-keeping related to crop loss.

$\mathrm{N}$ utritional E stimates

To estimate the nutritional content of salvageable food losses in the state, we used the previously estimated amounts of vegetables and berries grown in Vermont and pounds of salvageable loss for each of the seven berry types, 37 vegetable types, and an "other" category for each. To obtain data on nutrient composition, we matched each vegetable or berry with a corresponding code, or an average of multiple codes, from the National Nutrient D atabase for Standard Reference, Release 28 (SR-28) (USD A, Agricultural Research Service, Nutrient D ata Laboratory, 2015). We then 
calculated the amount of each nutrient in the salvageable loss and summed across food items to arrive at estimates by nutrient. To put the estimates in meaningful terms, we estimated the per capita, per day amount lost for each nutrient in terms of the average gap in dietary intake (national mean current intake minus Recommended Dietary Allowance or Adequate Intake) (Hellwig, O tten, \& Meyers, 2006). We presented data for selected nutrients that are underconsumed, and did not include data for highly consumed nutrients, such as calories.

\section{Sensitivity A nalyses}

Recognizing that crop loss may operate differently on farms of different sizes, our first sensitivity analysis was to weight the Q 1-Q 4 estimates by farm size. We decided not to treat this weighting as our main analysis, because while farmer estimates of percent harvested, edible, sold and donated seemed to differ by farm size, numbers at each size category were small and most differences were not statistically significant. We stratified estimates of percent salvageable loss by farm size category (vegetables: 0.1 to 4.9 acres [0.04 to 2 ha], 5 to 24.9 acres [2.02 to $10.08 \mathrm{ha}$ ], 25 to 99 acres [10.1 to 40.1 ha], 100 acres [ 40.5 hectares] and larger; berries: 0.1 to 4.9 acres, 5 acres and larger), and multiplied each estimate by the percentage of farms in the state in the relevant size category. State farm size data reflect "vegetables, potatoes and melons" and the berry items in "specified fruits and nuts" for 2012, the most recent year from which data were available (USD A National Agricultural Statistics Service, 2012a). We then summed across the size categories to obtain weighted means. These estimates are heavily influenced by the smaller farm size categories because the state has few larger farms and only a few of them responded to the survey.

We also performed three sensitivity analyses to assess the impacts on these estimates if some of the seemingly wasted food was actually eaten, via: gleaning other than that counted in the donation category; household consumption; and value-added products not otherwise counted. The major gleaning and donation collection operations in Vermont - the Vermont G leaning Collective (Salvation
Farms, 2015) and the Vermont Foodbank Gleaning Program (Vermont Foodbank, n.d.)- gleaned 617,696 lbs. $(280,182 \mathrm{~kg})$ in 2015. Based on our knowledge, a high percentage of this produce was picked up after harvest, and thus farmers would categorize it as donations rather than the unharvested category. Additionally, the produce that was "field gleaned" included apples, which are heavier than berries per volume. We nonetheless used $617,696 \mathrm{lbs}$. as a conservative estimate of vegetables and berries gleaned.

To assess the potential impact of direct consumption, we calculated the amount of produce if each vegetable and berry farm in the state fed a family of four people one pound each a day for four months during the growing season.

The third sensitivity analysis tested the effect of processing edible harvested produce (not sold or donated) into value-added products such as sauces. Two of the 26 surveyed berry farms reported value-added processing, so we estimated the impact if $7.7 \%$ (2 of 26) of unsold, undonated berries were processed into value-added products.

Lastly, we recalculated available crops using alternative crop yield estimates published by the University of Vermont Extension. While Rutgers published a single consolidated estimate covering vegetables on small farms $\left(0.5 \mathrm{lb} / \mathrm{ft}^{2}\right.$ or $\left.2.4 \mathrm{~kg} / \mathrm{m}^{2}\right)$ (Rabin et al., 2012), the Vermont estimate provided "low," "good," and "excellent" estimates for 42 distinct crops. " $G$ ood" yields ranged from 2,000 lbs/ acre (22,412 kg/ ha) (asparagus) to 40,000 lbs/ acre (44,834 kg/ ha) (onions, pumpkins). Because we did not have information about the crop mixes on included farms, we simply took the mean of all the estimates for "good" yield for vegetables, $0.44 \mathrm{lb} / \mathrm{ft}^{2}\left(2.15 \mathrm{~kg} / \mathrm{m}^{2}\right)$ (G rubinger, 2013).

\section{Results}

Fifty-eight farms, including 53 farms producing vegetables and 26 producing berries, completed the first part of the survey by providing estimates of percent harvested, edible, sold and donated. Fifty completed the full survey. All farms produced multiple products within the vegetable or berry categories, and 22 produced both vegetables and berries. In response to a request to list three of 
their main crops (Appendix B), farms listed six berry types- most commonly strawberries and blueberries, and 32 vegetable types- most commonly tomatoes and salad greens (multiple types). The farms represented 13 of 14 counties in Vermont. On average, vegetable farms were 16.4 acres (6.6 ha) (range 1-300), while berry farms were 2.5 acres (1 ha) (range 0.1-17). Compared to statewide figures, vegetable farms in our sample were less likely to be under 4.9 acres (1.98 ha) (54\% in our sample vs. $82 \%$ statewide) and more likely to be in the larger size categories, 5-24.9 acres (2-10.1 ha) (33\% vs. $15 \%$ ), $25-99.9$ acres (10.12- $40.43 \mathrm{ha})$ (9\% vs 3\%), and 100-249.9 acres (40.47-101.13 ha) (4\% vs $1 \%$ ) (USD A National Agricultural Statistics Service, 2012a). Berry farms in our sample

Table 2. Characteristics of Participating Farms, Including Acreage, Crops Grown, and Type of Sales, Vermont, 2016

\begin{tabular}{lcc}
\hline & $\begin{array}{c}\text { Vegetable Farms, } \\
\text { Mean (SD) }(n=53)\end{array}$ & $\begin{array}{c}\text { Berry Farms, Mean } \\
\text { (SD) }(n=26)\end{array}$ \\
\hline Acreage & $16.6(51.4)$ & $2.5(3.9)$ \\
\hline \# of types of vegetables/ berries grown & $34(26.7)$ & $4.6(3.1)$ \\
\hline Type of sales & \multicolumn{2}{c}{$\%$ of farms $(n=50)$} \\
\hline \multicolumn{2}{c}{ Direct sales to restaurants, retail } & $75 \%$ \\
Wholesale in state & $61 \%$ \\
Farmers market & $55 \%$ \\
Farm stand & $51 \%$ \\
CSA & $47 \%$ \\
Wholesale out of state & $35 \%$ \\
\hline
\end{tabular}

were more likely than farms statewide to be under 5 acres (88\% vs. $76 \%$ ), and less likely to be 5 acres and greater (13\% vs. $24 \%)$ (USD A National Agricultural Statistics Service, 2012a). The farms represent a convenience sample and are not a randomly selected sample of Vermont farms. Table 2 describes participating farms.

Q uantifying $\mathrm{V}$ ermont $\mathrm{V}$ egetable and Berry L oss Figure 3 presents Sankey diagrams depicting farmers' mean estimates of the fate of available vegetables and berries as the available supply is split between harvested and not harvested, and as these are subsequently split into sold, unsold, donated, edible and inedible. As shown in Table 3, farmers estimated that on average, about $85 \%$ of available crops were harvested on both vegetable and berry farms (vegetable $25^{\text {th }}$ percentile: $80 \%$, $75^{\text {th }}$ percentile: $93 \%$; berries $25^{\text {th }}$ percentile: $85 \%, 75^{\text {th }}$ percentile $98 \%$ ). On vegetable farms, they considered 34\% of those unharvested crops edible (25 $5^{\text {th }}$ percentile $5 \%, 75^{\text {th }}$ percentile $75 \%$ ), and on berry farms, $25 \%$ on average ( $25^{\text {th }}$ percentile $2 \%, 75^{\text {th }}$ percentile $36 \%$ ). Of crops that were harvested, vegetable farmers estimated that about $81 \%$ were sold $\left(25^{\text {th }}\right.$ percentile $80 \%, 75^{\text {th }}$

Figure 3. Fate of Available (a) Vegetables and (b) Berries, Based on Survey Performed in Vermont, 2016
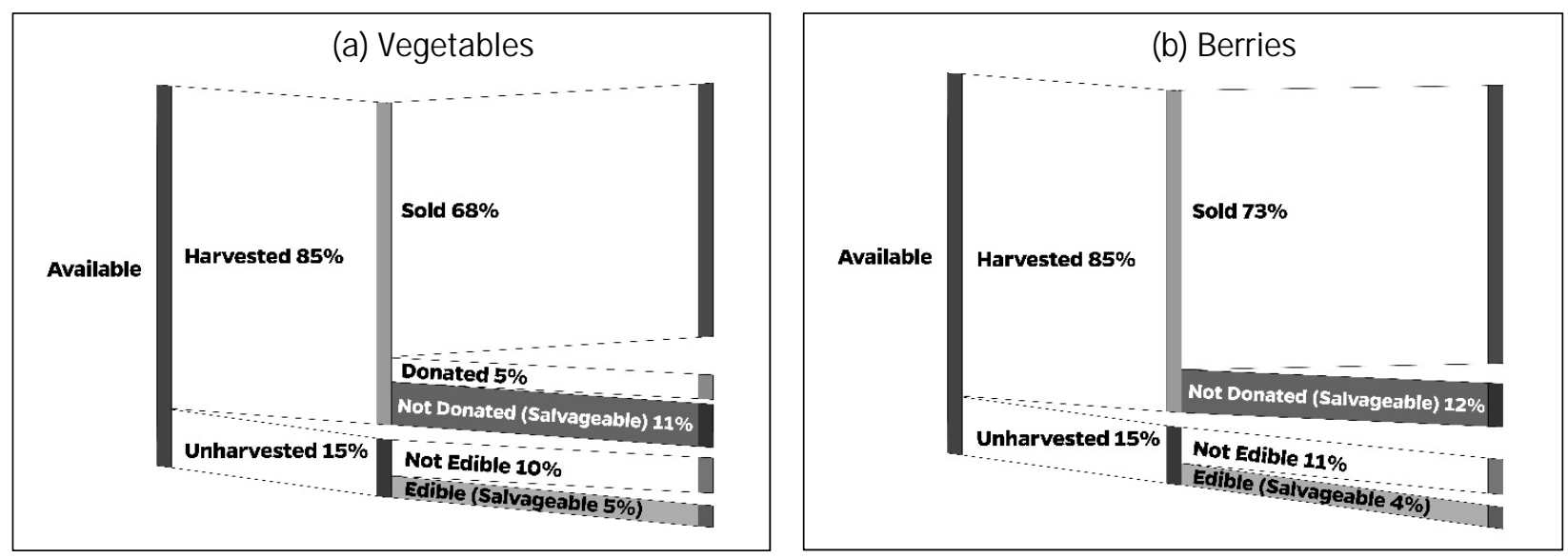

Note: Percent of berries donated was too small to appear in chart 3(b). Depicted percentages reflect means; Table 3 presents ranges. 
percentile $92 \%$ ), while fruit farmers estimated $86 \%$ were sold $\left(25^{\text {th }}\right.$ percentile $95 \%$, $75^{\text {th }}$ percentile $99 \%$ [results were skewed]). Vegetable farmers estimated that they donated $33 \%$ of the unsold produce on average ( $25^{\text {th }}$ percentile $5 \%, 75^{\text {th }}$ percentile $\left.51 \%\right)$, while berry farmers said they donated about four percent on average $\left(25^{\text {th }}\right.$ percentile $0 \%, 75^{\text {th }}$ percentile $2 \%$ ). Accordingly, we estimate that within the sample, on average $16 \%$ of available vegetables and $15 \%$ of berries could be considered salvageable loss (unharvested but edible + harvested but neither sold nor donated). For the average farm in the sample, this loss totaled over

Table 3. Estimated Salvageable Loss of Vegetables and Berries on Sampled Farms in Vermont, 2016, Based on Estimated Quantities Lost, Sold, and Donated: Mean Weight

\begin{tabular}{|c|c|c|c|c|}
\hline & \multicolumn{2}{|c|}{ Vegetables } & \multicolumn{2}{|c|}{ Berries } \\
\hline & Mean & $\mathrm{N}$ & Mean & $\mathrm{N}$ \\
\hline Acreage & 15.1 & 54 & 2.5 & 26 \\
\hline Yield fraction & $0.5 \mathrm{lb} / \mathrm{ft}^{2}$ & & $0.15 \mathrm{lb} / \mathrm{ft}^{2}$ & \\
\hline Quantity available for harvest (lb.) & 330,794 & & 16,228 & \\
\hline Percent harvested & 84.7 & 53 & 85.0 & 26 \\
\hline Percent sold & 80.7 & 53 & 86.2 & 25 \\
\hline Percent donated of unsold & 33.2 & 51 & 3.8 & 25 \\
\hline Percent edible of unharvested & 34.0 & 53 & 24.7 & 25 \\
\hline Quantity harvested (Ib.) & 280,182 & & 13,800 & \\
\hline Quantity not harvested (Ib.) & 50,611 & & 2,428 & \\
\hline Quantity not harvested but edible (Ib.) & 17,208 & & 599 & \\
\hline Quantity sold (lb.) & 226,107 & & 11,890 & \\
\hline Quantity not sold (lb.) & 54,075 & & 1,910 & \\
\hline Quantity donated (Ib.) & 17,953 & & 72 & \\
\hline Quantity neither sold nor donated (lb.) & 36,122 & & 1,838 & \\
\hline Salvageable Loss & 53,330 & & 2,437 & \\
\hline$\%$ Salvageable Loss & $16 \%$ & & $15 \%$ & \\
\hline Vegetables + Berries & Mean & & & \\
\hline Total available for harvest & 347,022 & & & \\
\hline Total not harvested and edible & 17,807 & & & \\
\hline Total not sold and not donated & 37,960 & & & \\
\hline Total Salvageable Loss & 55,767 & & & \\
\hline \% Salvageable Loss & $16 \%$ & & & \\
\hline
\end{tabular}

Notes: Percentiles refer to acreage and farmer percent harvested, sold, donated and edible. Some of the subsequent calculations result in higher quantities of crops in the $25^{\text {th }}$ percentile or median column than in the $75^{\text {th }}$ percentile. In some cases, all three percentile estimates were lower than the mean due to unevenly distributed results. $1 \mathrm{lb}=0.45 \mathrm{~kg} ; 1$ acre $=43,560 \mathrm{ft}^{2}$ an estimated $53,000 \mathrm{lbs} .(24,000 \mathrm{~kg})$ of vegetables and 2,440 lbs. (1,107 kg) of berries. Table 3 also presents the median and interquartile ranges, based on farmer responses, for these estimates. As will be discussed, these estimates may be affected by record-keeping limitations.

Farms that responded to Part 2 of the survey also provided additional contextual information. Most farms reported losing "very little" produce at the washing and packaging stage (66\% of farms) or in storage $(57 \%)$, while $60 \%$ reported losing no produce during transportation.

We asked farmers about the fate of unharvested and unsold crops, allowing the option to indicate multiple destinations. Results were similar for vegetables and berries and thus are combined here. For unharvested crops, $64 \%$ of farms reported turning the crops under the soil, $28 \%$ fed them to pasturing animals, and $20 \%$ allowed gleaning or food rescue groups to pick them. For unsold crops, $61 \%$ of farms indicated that the farmer's family ate some, $59 \%$ each donated some to community groups and composted the crops, $47 \%$ fed some to animals. Two berry farms $(7.7 \%)$ reported processing some crops into value-added products.

\section{Reasons for Vegetable and Berry Losses} The top reasons farmers reported for not harvesting edible produce were blemishes (48\%) and a lack of confidence that 
they could sell the produce (41\%), followed by lack of available labor (31\%) and lack of affordable labor $(10 \%)$. Write-in responses included competing harvesting priorities, leaving them with a lack of time to both harvest and prepare produce for market, as well as inadequate storage bins and space to keep the produce.

The top reasons farmers gave for not being able to sell their produce after harvest were a lack of demand (47\%), oversaturation of the market

Figure 4. Services Participating Farmers Would Appreciate from Community Groups, Vermont, 2016

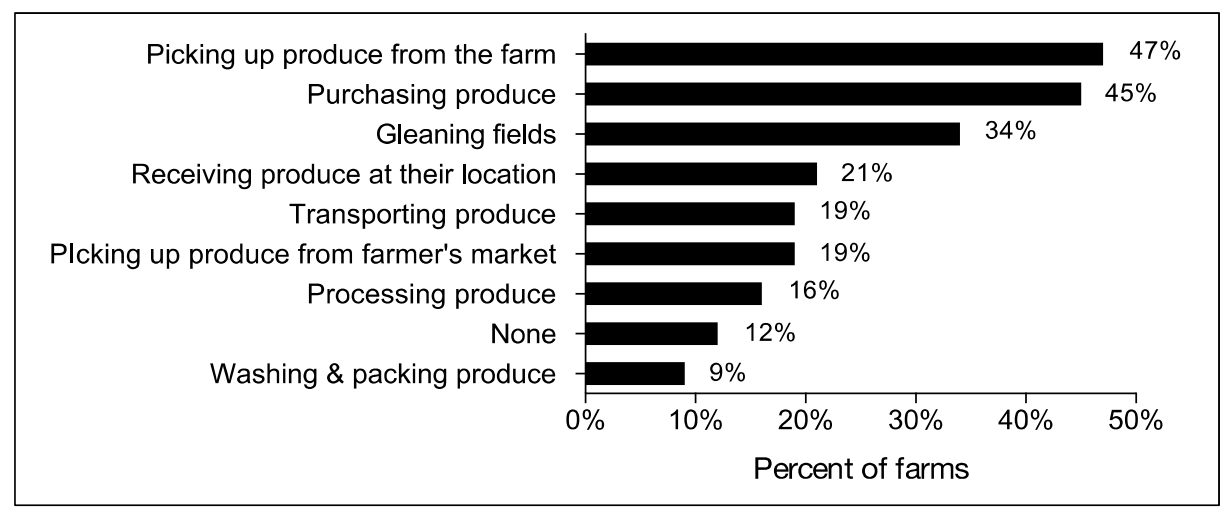

Table 4. Estimated Crops Lost, Sold, and Donated in Vermont in Pounds, Modeled Based on 2016 Survey

\begin{tabular}{lcc}
\hline & $\begin{array}{c}\text { Farms Producing } \\
\text { Vegetables, } \mathrm{n}=53\end{array}$ & $\begin{array}{c}\text { Farms Producing } \\
\text { Berries, } \mathrm{n}=26\end{array}$ \\
\hline Total farm acreage & 3,897 & 601 \\
\hline Yield fraction applied & $0.5 \mathrm{lb} / \mathrm{ft}^{2}$ & $0.15 \mathrm{lb} / \mathrm{ft}^{2}$ \\
\hline Total quantity available for harvest (lb) & $84,876,660$ & $3,926,934$ \\
\hline$\%$ Harvested & 84.7 & 85 \\
\hline \% Sold & 80.7 & 86.2 \\
\hline$\%$ Donated (unsold) & 33.2 & 3.8 \\
\hline$\%$ Edible (unharvested) & 34 & 24.7 \\
\hline Harvested (lb) & $71,890,531$ & $3,337,894$ \\
\hline Sold (lb) & $58,015,659$ & $2,877,265$ \\
\hline Donated (lb) & $4,606,458$ & 17,504 \\
\hline Not sold, not donated (lb) & $9,268,415$ & 443,125 \\
\hline Not harvested (lb) & $12,986,129$ & 589,040 \\
\hline Not harvested but edible (lb) & $4,415,284$ & 145,493 \\
\hline Salvageable loss (lb) & $13,683,699$ & 588,618 \\
\hline$\%$ of available harvest that was salvageable loss & $16.1 \%$ & $15.0 \%$ \\
\hline
\end{tabular}

Note: $1 \mathrm{lb}=0.45 \mathrm{~kg} ; 1$ acre $=0.40 \mathrm{ha} ; 1 \mathrm{lb} / \mathrm{ft}^{2}=4.9 \mathrm{~kg} / \mathrm{m}^{2}$
(43\%), and blemishes on fully edible produce (34\%). In some cases, produce became partially or fully inedible before being sold (10\%), such as due to lettuce wilting at farmers markets and potatoes deteriorating in storage while seeking wholesale or direct markets.

Interventions to Recover Crops

We asked farmers about their interest in a set of services that could be provided by community groups (Figure 4). Nearly half said they would like community groups to pick up produce from the farm $(47 \%)$ or purchase their produce $(45 \%)$.

The survey explored the use of the federal enhanced tax deduction currently available to farmers for donating food. Of respondents, $92 \%$ said they did not claim this deduction for 2015 food donations or were unsure if they had. Only $26 \%$ of farms were 'probably' or 'definitely' planning to claim federal tax deductions for food donations in 2016. Additionally, 62\% expressed interest in having the state of Vermont develop a program to provide financial compensation for donating food.

Statewide F ood L oss E stimates We extrapolated from the survey data to generate salvageable loss estimates for all of Vermont (Table 4). We estimate that overall, 
$13,684,000 \mathrm{lbs} .(6,207,000 \mathrm{~kg})$ of vegetables and $589,000 \mathrm{lbs}$. (267,000 kg) of berries may have been lost across Vermont in 2012.

\section{Sensitivity A nalyses}

The first sensitivity analysis involves statewide weighting estimates by farm size because the farmer estimates related to crop loss appeared to vary by farm size (not statistically significant). We did not incorporate this analysis into the main result because the number of farms is small, so segmenting by crop size creates even smaller cells, leading to reduced confidence in the accuracy of estimates. As shown in Appendix C, table C1, farms lost $16.8 \%$ of vegetables (vs. $16.1 \%$ unweighted), leading to an estimate of $14,256,000$ lbs. $(6,466,000 \mathrm{~kg})$ salvageable loss (vs. $13,684,000$ lbs. or $6,207,000 \mathrm{~kg}$ unweighted). In the weighted estimates, berry farms lost $10.7 \%$ of crops by weight (vs. 15.0\% unweighted), or an estimated 419,000 lbs. (190,000 kg) (vs. 589,000 lbs. $(267,000$ $\mathrm{kg}$ ) unweighted).

It is possible that some of the seemingly wasted food was in fact eaten, via: gleaning that was not counted in the donation category; direct consumption; and value-added products. While we expect that most gleaning would be considered by farmers as donated rather than unharvested, in our sensitivity analysis we subtracted the 2015 quantity gleaned by two major collection operations in the state (Vermont G leaning Collective and Vermont Foodbank G leaning Program)-617,696 pounds (280,182 kg) - from the estimated statewide loss.

In the next analysis, we assumed that each vegetable farm (789) and berry farm (535) in the state provided one pound per person per day to a family of four for 120 days during the growing season. The total would be $635,520 \mathrm{lbs}$. $(288,267$ $\mathrm{kg}$ ) of produce. This estimate might be high because some farms are double-counted since they produce both crops, and because consumption levels may be lower than $1 \mathrm{lb}(0.45 \mathrm{~kg})$, or it might be low if farmworkers are also consuming the crops directly.

The third sensitivity analysis was based on the fact that some farms may not have included crops they processed into value-added products as "sold" or "donated," meaning these would be counted as a loss. Two of the 26 berry farms in our study reported such processing, so we conservatively estimated the effect of processing $7.7 \%$ of unsold, un-donated berries into valueadded products. If this happened, 34,086 lbs. $(15,461 \mathrm{~kg})$ of berries would be removed from the loss category statewide.

Lastly, we explored alternate estimates of the average yield per acre. The analysis is based on an estimate of $0.5 \mathrm{lb} / \mathrm{ft}^{2}\left(2.44 \mathrm{~kg} / \mathrm{m}^{2}\right)$ for vegetable yields from Rutgers University (Rabin et al., 2012), based on their similarity to farms in Vermont. As a robustness check, we recalculated based on cropspecific yield estimates published by the University of Vermont Extension - which averaged to 0.44 $\mathrm{lb} / \mathrm{ft}^{2}\left(2.15 \mathrm{~kg} / \mathrm{m}^{2}\right)$ for vegetables (G rubinger, 2013). In the statewide calculation using this value, the estimated salvageable loss for vegetables drops from about $13,684,000 \mathrm{lbs}$. $(6,207,000 \mathrm{~kg})$ to about $12,042,000$ lbs. $(5,462,000 \mathrm{~kg})$.

Combining the five sensitivity analyses would reduce the estimated salvageable vegetable and berry loss by $13 \%$, or $1,891,500 \mathrm{lbs}$. (857,970 kg), to $12,381,000 \mathrm{lbs}$. $(5,616,000 \mathrm{~kg})$, as shown in Appendix D.

F ood L oss E stimates by C ounty Vegetable and berry production is not evenly distributed across the state of Vermont. For example, 830 acres (336 ha) of vegetables were harvested in Chittenden County, but only 19 acres (7.7 ha) in Essex County. Applying statewide loss rates to acres planted, we estimated vegetable and berry loss by county (Figure 5). Based on their higher production, Chittenden and Windham counties are estimated to have the highest vegetable and berry losses, each exceeding 2.6 million pounds $(1,179,000 \mathrm{~kg})$ of vegetable loss and 97,000 lbs. $(44,000 \mathrm{~kg})$ of berry loss.

E stimates of L ost $\mathrm{N}$ utrients

We estimated the quantities of lost nutrients statewide. Table 5 displays results for a selection of nutrients classified as under-consumed, meaning that average intakes in the U.S. fall short of recommended amounts, and that are rich in vegetables and berries (U.S. D epartment of Health and Human Services \& U.S. D epartment of 
Figure 5. Vegetable and Berry Loss by Vermont County, Modeled Based on 2016 Survey and County Acres Planted

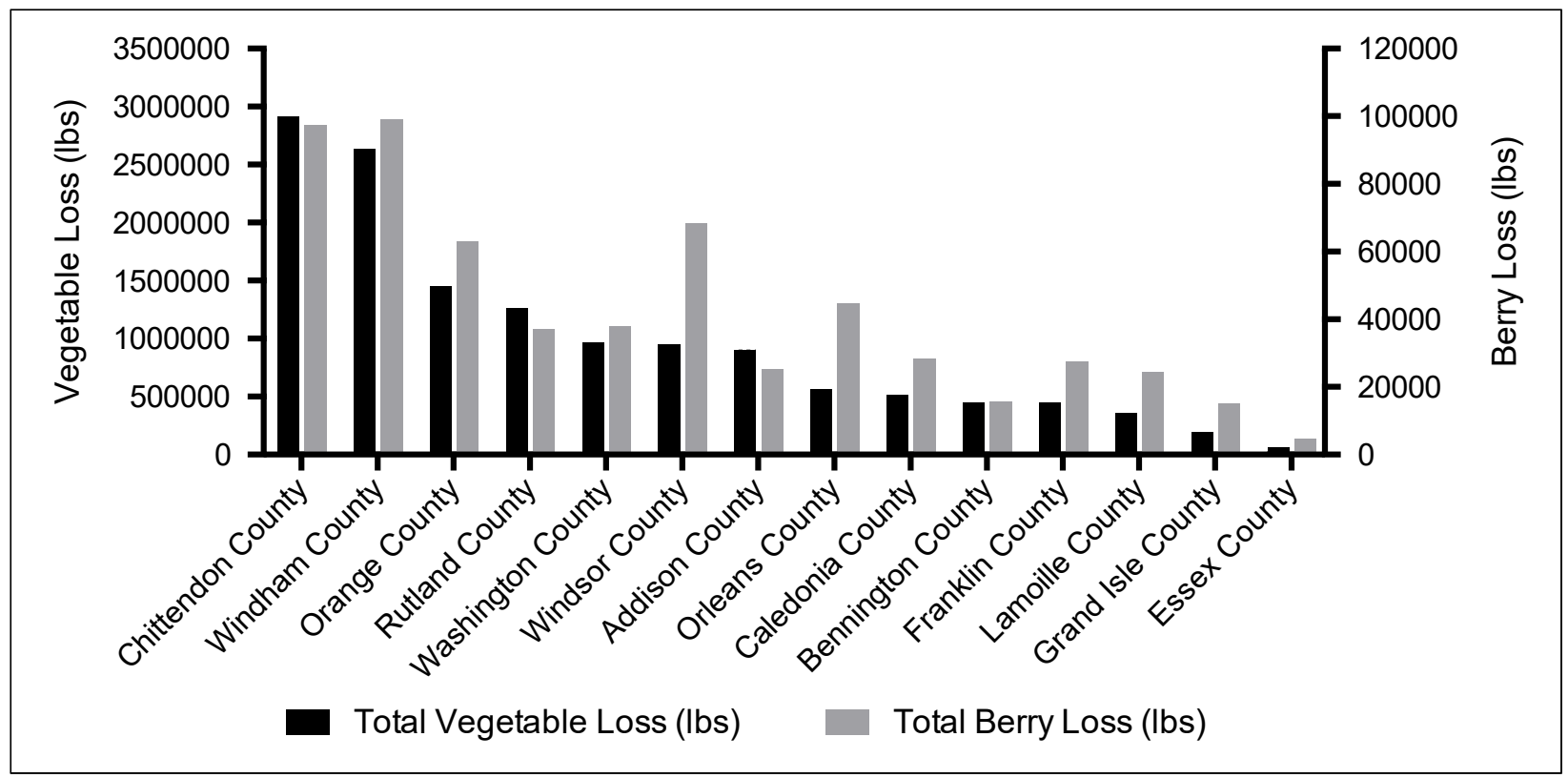

Data source: USDA National Agricultural Statistics Service, $2012 \mathrm{~b}$.

Agriculture, 2015). We focus on the difference between the average amount consumed and recommended (referred to here as the "gap"). This analysis finds that the nutritional content of salvageable vegetables and berries wasted each day in Vermont in 2012 contained an amount of Vitamin A equivalent to the gap between consumption and recommendations for about 221,000 adult women, calcium for 33,000 adult women, iron for 29,000 adult women, potassium for 21,000 adult women, and fiber for 36,000 adult women. Results are also shown for adult men, for whom gaps in dietary intake differ.

Record-k eeping

As future efforts to understand farm-level crop

Table 5. Nutritional Content of Salvageable Vegetable and Berry Losses in Vermont (Modeled), for Selected Nutrients

\begin{tabular}{|c|c|c|c|c|c|}
\hline Nutrient & $\begin{array}{l}\text { Nutritional content } \\
\text { of salvageable loss } \\
\text { of vegetables and } \\
\text { berries (average per } \\
\text { capita per day) }\end{array}$ & $\begin{array}{l}\text { Average gap in } \\
\text { dietary intake for } \\
\text { adult women: } \\
\text { National mean } \\
\text { current intake minus } \\
\text { Recommended } \\
\text { Dietary Allowance or } \\
\text { Adequate Intake }\end{array}$ & $\begin{array}{l}\text { Equivalent number } \\
\text { of gaps in dietary } \\
\text { intake for adult } \\
\text { women from } \\
\text { salvageable loss } \\
\text { statewide }\end{array}$ & $\begin{array}{c}\text { Average gap in } \\
\text { dietary intake for } \\
\text { adult men: National } \\
\text { mean current intake } \\
\text { minus } \\
\text { Recommended } \\
\text { Dietary Allowance or } \\
\text { Adequate Intake }\end{array}$ & $\begin{array}{l}\text { Equivalent number } \\
\text { of gaps in dietary } \\
\text { intake for adult men } \\
\text { from salvageable } \\
\text { loss statewide }\end{array}$ \\
\hline Vitamin A & $34.2 \mathrm{mcg}$ & $-97 \mathrm{mcg}$ & 220,740 adults & $-151 \mathrm{mcg}$ & 141,800 adults \\
\hline Vitamin E & $0.12 \mathrm{mg}$ & $-7.3 \mathrm{mg}$ & 10,073 adults & $-4.7 \mathrm{mg}$ & 15,646 adults \\
\hline Calcium & $6.9 \mathrm{mg}$ & $-132 \mathrm{mg}$ & 32,745 adults & $+116 \mathrm{mg}$ & N/A \\
\hline Iron & $0.2 \mathrm{mg}$ & $-4.4 \mathrm{mg}$ & 28,708 adults & $+10.1 \mathrm{mg}$ & $\mathrm{N} / \mathrm{A}$ \\
\hline Magnesium & $6.3 \mathrm{mg}$ & $-36 m g$ & 109,315 adults & $-44 \mathrm{mg}$ & 89,439 adults \\
\hline Potassium & $78.4 \mathrm{mg}$ & $-2288 \mathrm{mg}$ & 21,459 adults & $-1505 \mathrm{mg}$ & 32,623 adults \\
\hline Dietary Fiber & $0.5 \mathrm{~g}$ & $-8.9 \mathrm{~g}$ & 36,075 adults & $-17.7 \mathrm{~g}$ & 18,139 adults \\
\hline
\end{tabular}

Source: Nutritional data from USDA, and RDA/ Al data from Hellwig, Otten, \& Myers, 2006.. 
losses proceed, it is valuable to understand the extent to which farmers currently keep records of quantities relevant for this assessment. In our survey, most participating farmers reported recording the amount of crops planted (74\%), harvested (67\%) and sold (69\%). Few, however, kept records of other quantities important for tracking food losses, including amount not harvested (3\%), amount damaged during washing and packaging or during storage ( $2 \%$ each), and amount damaged during transportation (0\%). Farmers most commonly recorded information on paper, closely seconded by computer (commonly Excel or Q uickbooks). Many used both paper and computer. Few recorded data on smartphone applications.

\section{Discussion}

This research provides the first survey-generated estimate of farm-level food losses in Vermont and contributes estimates and a methodology to the small body of langely non-peer-reviewed literature on farm-level food loss in the U.S. These findings for Vermont may shed light on quantities of farmlevel food loss elsewhere, primarily on farms that are small and selling via direct markets, and particularly those with similar planting conditions.

Previous E stimates of $0 \mathrm{n}-\mathrm{F}$ arm C rop L oss in the U.S. Our estimate of 14.3 million pounds $(6,500,000 \mathrm{~kg})$ of vegetable and berry loss far exceeds Salvation Farms' previous Vermont estimate of 2 million pounds $(907,000 \mathrm{~kg})$ across all crop types (developed based on observation of farming and crop rescue in the state). Even with sensitivity analyses, the estimate would only drop to 12.4 million pounds $(5,625,000 \mathrm{~kg})$. Nonetheless, our estimate that $16.1 \%$ of vegetables and $15.0 \%$ of salvageable berries were lost does fall within the range of the three other estimates of U.S. farm-level crop losses we identified.

First, the FAO estimates that $20 \%$ by weight each of fruits, vegetables, and tubers are lost annually during production (Gustavsson et al., 2013). The fruit and vegetable estimates are based on a study including carrots, onions, and tomatoes from two to three large farms per product in Sweden. That study does not provide its methods of estimating loss percentage but does state that there is large variation in FLW between crops (D avis et al., 2011). The FAO estimates for North America are further shaped by a U.K. estimate that $25-40 \%$ of most fruit and vegetable crops are rejected by supermarkets (G ustavsson et al., 2013).

The second identified estimate of U.S. farmlevel crop loss comes from the ReFED collaborative of wasted food stakeholders, which estimates conservatively that $13.1 \%$ of crops are lost at the farm level (10.1 million tons [9.2 metric tons]), based only on cosmetic imperfection rates found in one survey in Minnesota. For comparison to Vermont, they identified an imperfection rate of $10 \%$ for berries, an average of $13 \%$ for multiple vegetables, and 15\% for potatoes in Minnesota (Berkenkamp, 2016). ReFED estimated that less than $5 \%$ of the loss was recovered for human consumption, primarily through farm-to-food-bank programs (ReFED , 2016).

Finally, a study commissioned by the Natural Resources D efense Council estimates farm-level fruit losses ranging from $3 \%$ (low-end estimate, cherries) to $60 \%$ (high end, plums); and vegetable losses from $5 \%$ (low end, lettuce) to 22\% (high end, broccoli) (Milepost Consulting, 2012). These estimates were based on interviews with large commercial produce growers and shippers in California.

While methodological differences partly shape the differences in these estimates, we emphasize that farm-level food waste will vary considerably by crop, geographic factors, farm size and more.

\section{Reasons for L oss}

This survey identified a set of proximal reasons for crop loss which were generally consistent with findings described in other studies: aesthetics, challenges in selling the produce due to demand fluctuations and market saturation, and labor availability and costs. We note that underlying each of these reasons is a set of deeper reasons. For example, aesthetics challenges arise from factors including weather and pests; consumer demand; purchaser expectations; and produce standards. Moreover, market saturation can be linked partly to the fact that it is economically beneficial to overproduce crops to insure against potential 
losses. D emand fluctuations are affected by many factors including the contracts made with purchasers and even changes in weather that affect consumer consumption patterns. Labor availability may be traced in part to immigration policy and to relatively low produce costs that can make it difficult to pay a living wage. Also, because farms are vulnerable to weather and other conditions, and many smaller produce farms do not have crop insurance, overplanting is commonly practiced to increase the likelihood of having a profitable season. Another norm affecting farm-level waste is the fact that prices for a product typically drop over the course of a season, and plants may become damaged over time, reducing the amount of quality produce that can be harvested. Accordingly, it can become economically unwise to continue harvesting even as crops remain unpicked (Creamer, 2017).

We also emphasize that farm-level food waste is heavily linked with waste at other stages of the supply chain. For example, decisions regarding whether to harvest crops and the ability to sell some crops are shaped by retailer preferences, which to an extent are shaped by consumer preferences. Practices on the farm, from harvest timing to storage to packaging, also have important impacts on losses further up the food chain that may ordinarily be attributed to consumers or retailers.

A ddressing $\mathrm{V}$ ermont $\mathrm{F}$ ood L osses There is no silver bullet intervention to address farm-level food losses. Strategies must be tailored, and it will be necessary to address the problem from multiple levels at once.

The U.S. EPA's Food Recovery Hierarchy indicates that the priority in addressing food loss and waste should be prevention, or reducing excesses at the source (U.S. EPA, n.d.-b). Addressing the aforementioned reasons for loss requires strategically selected approaches aimed at either preventing the risk factor for loss (e.g., improving strategies for crop protection from weather or pests), or finding ways to manage it (e.g., identifying good markets for all grades of produce and determining how best to connect farmers to them). Infrastructure, technology, staffing levels, financing, experience, and luck all play roles.

The second priority in the hierarchy is recovering food for people to eat. Farmers indicated that they already donated about 32\% of unsold produce from vegetable farms and $4 \%$ from berry farms. The latter was presumably lower due to the fragility and perishability of berries. Farms identified a variety of services they would consider helpful in this regard. To help address food insecurity, over $60 \%$ expressed interest in a state program that would compensate farmers for donations. A federal tax deduction was extended to all farms in D ecember 2015. As farmers and farm service agents become more informed of this change, farms may increasingly take advantage of this resource for their eligible food donations.

Lower priorities in the EPA Food Waste Recovery hierarchy include feeding the crops to animals and composting them or sending for anaerobic digestion to produce energy. While these are usually not optimal, especially for high-quality crops, they are efficient and economical on-farm practices that have value for a farm. Half or more of surveyed farmers reported these approaches. Tradeoffs exist in cost, time, and environmental impact, and it is not always preferable to perform the extra work to reduce the last small quantities of loss, especially when alternate benefits can be obtained from the materials.

\section{Record-Keeping}

The research revealed that few farmers were keeping records needed to enable them to track their own losses. Providing easy to use tools may be valuable for advancing this practice. Maintaining such records is beneficial not only for broader tracking efforts, but also because it helps to build motivation for action to reduce losses, to shape targeted responses to key risk factors, and to enable farmers to track progress toward reducing loss. Such records could also aid in assessing potentially available fruits and vegetables for donations or processing.

Strengths and Limitations This research presents an innovative survey-based approach for estimating food losses at the farm level, contributing to addressing an important 
research gap. It complements farmer estimates of waste quantities with multiple types of contextual information. The research goes beyond the direct findings to model results at the state and county level. It also provides the first estimates of nutrient content of crop losses at the state level.

The food loss estimate has several limitations. First, the calculations are based on small numbers of farms ( 53 vegetable and 26 berry farms), and they were recruited through convenience sampling, so participants may have been particularly interested in crop losses. Selection bias could lead to increased waste estimates if participants have a higher awareness of their farm's discards, or to decreased waste estimates if participants are already active in waste-reduction. Second, findings were based on post-season estimates of percent harvested, sold, edible, and donated. Most farmers did not maintain the records needed to quantify these figures definitively. Self-reported estimates are subject to recall bias, use of heuristics to simplify the task of developing estimates, aspiration bias, and social desirability bias - with the likelihood of the latter increased by the request to include the farm name. Third, the estimates of pounds wasted are shaped by the volume of crops available for harvest, which in turn are shaped by the selected estimates for crop yield per acre. The sensitivity analysis using a different crop yield estimate yielded a result about $12 \%$ lower. Fourth, there may have been diverse understandings among the farmers of terms, including "edible" and "inedible"; "sold" (whether to include value-added crops); and "donated" (whether to include gleaned crops). Q uestion 1 regarding percent of crops harvested did not specify that we intended the denominator to be crops that grew successfully rather than the entire initial planting, as we perceived that to be implicit.

We performed additional sensitivity analyses for other potential sources of error. These assessments mostly used conservative assumptions that likely overstated impact, and combined they would have reduced estimated salvageable statewide losses by $13 \%$, to $12,389,000 \mathrm{lbs}$. $(5,620,000 \mathrm{~kg})$.

We also note that statewide data come from the 2012 A gricultural Census, whereas our survey took place in 2016, generating estimates for the 2015 growing and harvest season. We do not believe substantial changes in farm size and production have taken place in that time.

Future Research

We identify multiple research needs to improve estimates of farm-level food waste. First, it would be valuable for future studies to survey larger, randomly collected samples of farmers and to collect data directly rather than relying on recall and estimation. Research should also focus more specifically on widely grown crop items, particularly fruits, which may represent a valuable opportunity for gleaning, donations, and new market development. It would also be valuable to measure the amounts of vegetables and berries lost during washing, packaging, storage, and transportation. While no farmers in the Vermont Food Loss Survey said that they lost "a lot" of produce during any of these stages, a few did say they lost a "moderate amount." Further exploration is needed to understand better how farmers interpret these quantities, both quantitatively and qualitatively. Another research gap in the quantification of farmlevel waste is understanding how much unsold, undonated produce goes to direct consumption, value-added products, animal feed, compost, anaerobic digestion, and other destinations.

This study also highlights research needed to improve responses to farm-level losses. First, there is a need for evaluations to understand the impacts of diverse strategies aimed at reducing the amount of food loss in Vermont, including new market development. A particular question is the extent to which the federal tax deduction is functioning as an incentive to increase donations or a benefit for those who would donate regardless-and what the Vermont financial compensation should look like in order to best support farmers and further reduce food loss. Lastly, additional research is necessary to understand how farmers can better partner with gleaning, food rescue, and farm surplus management organizations to reduce food loss and address food insecurity in Vermont, and how these operations can be better supported to advance their operations and enable properly valuing these public services that today are often performed by volunteers. 


\section{Conclusions}

An estimated 14.3 million pounds (6,500,000 kg) of edible vegetables and berries may be lost each year in Vermont. This food is either left unpicked in the fields or is picked but neither sold nor donated. Improved record-keeping is needed to strengthen these estimates. This research can undergird future efforts to assess the potential for preventing losses and recovering food for human consumption, and to examine tradeoffs in cost and environmental impacts. It may not be feasible or preferable to recover all crops that are lost, given challenges in logistics, perishability, and the disproportionate effort needed to reduce the last bits of waste. Nonetheless, the quantities of farm-level loss suggested in this research indicate there might be great potential to prevent crop losses and to scale up food recovery efforts from farms.

In order to capture more of this large amount of food loss, a robust food loss management plan would be beneficial in Vermont, with farmers at the core. This plan should advance food loss prevention interventions; expand market opportunities for farmers; compensate farmers for donating the foods they produce that are not sold or eaten; and support larger-scale, professionalized gleaning, food rescue, and farm surplus management operations that strengthen farms and the regional food system and increase availability of produce for those in need. It should also provide farmers with tools to assist in quantifying losses and decision tools to assist them in determining when to expend the effort in recovering them. In each of these ways, farmers will benefit and more food will enter the local food system. From farmers to gleaners, food rescuers to policymakers, and consumers to purchasers, everyone can play a role in right-sizing production and in capturing more of this healthy food that otherwise is lost.

\section{Acknowledgments}

We extend our thanks to the dozens of farmers who lent us their time and insights by filling out the Vermont Food Loss Survey. We are very grateful to the many farmers we interviewed from across the state during the survey development stage, as well. We could not have obtained such a great response from farmers without the support of the many partners who distributed the Vermont Food Loss Survey to their farmer network. This includes the Vermont V egetable and Berry G rowers Association, NOFA-Vermont, the Vermont Foodbank, and the Vermont Gleaning Collective members (RAFFL, HOPE, the Intervale Center, Community Harvest of Central Vermont, and the Northwest Vermont Healthy Roots Collaborative).

We also thank the following for review of the original report or this manuscript: Laurie Beyranevand, Robert Q . Bui, Vern G rubinger, Jane Kolodinsky, and Jim Yager. Two anonymous JAFSCD reviewers also made important contributions.

\section{References}

Berkenkamp, J. (2016). Beyond beauty: The opportunities and challenges of cosmetically imperfect produce. Retrieved from http:/ / ngfn.org/ resources/ ngfn-cluster-calls/ beyond-beauty - section-1

Buzby, J. C., Farah-Wells, H., \& Hyman, J. (2014). The estimated amount, value, and calories of postharvest food losses at the retail and consumer levels in the U nited States. Washington, D .C.: USD A.

Creamer, N. (2017). Introducing farm-level loss into the food waste discussion. H uffP ost: The Blog. Retrieved from http:/ / www.huffingtonpost.com/ nancy-creamer/ introducing-farm-level-lo b 13941104.html

Davis, J., Wallman, M., Sund, V., Emanuelsson, A., Cederberg, C., \& Sonesson, U. (2011). E missions of greenhouse gases from production of horticultural products: A nalysis of 17 products cultivated in Sweden. Retrieved from http:// www.divaportal.org/ smash/ get/ diva2:943913/ FULLTEXT01.pdf

Feeding America. (2017). M ap the M eal G ap 2017. Retrieved from Washington, D .C.: http:/ / www.feedingamerica.org/ mapthegap

Food and Agriculture O rganization of the United Nations [FAO ]. (2011). G lobal food losses and food waste: E x tent, causes and prevention. Retrieved from http:/ / www.fao.org/ docrep/ 014/ mb060e/ mb060e00.pdf

Grubinger, V. (2013). V egetable and berry crop yield estimates for N ew E ngland. Burlington: University of Vermont Extension. Retrieved from https:// www.uvm.edu/ vtvegandberry/ factsheets/ vegetableberryyields.pdf 
Journal of Agriculture, Food Systems, and Community D evelopment

ISSN: 2152-0801 online

https:/ / www.foodsystemsjournal.org

Gustavsson, J., Cederberg, C., Sonesson, U., \& Emanuelsson, A. (2013). The methodology of the FA 0 study: "G lobal F ood L osses and F ood W aste ex tent, causes and prevention." Göteborg: The Swedish Institute for Food and Biotechnology.

Hanson, K., \& Connor, L. (2014). Food insecurity and dietary quality in US adults and children: A systematic review. A merican Journal of Clinical N utrition, 100(2), 684-692. https:/ doi.org/ 10.3945/ ajcn.114.084525

Hellwig, J., O tten, J., \& Meyers, L. (2006). D ietary reference intakes: The essential guide to nutrient requirements. Washington, D .C.: National Academies Press.

Milepost Consulting. (2012). L eft out: A n investigation of the causes and quantities of crop shrink. Retrieved from https:/ / www.nrdc.org/ sites/ default/ files/ hea_12121201a.pdf

Rabin, J., Zinati, G ., \& Nitzsche, P. (2012). Y ield ex pectations for mix ed stand, small-scale agriculture. Issue brief. (Vol. 7). Rutgers: Rutgers New Jersey Agricultural Experiment Station.

ReFED . (2016). A roadmap to reduce U S food waste by 20 percent. Retrieved from http:// www.refed.com

Salvation Farms. (2015). Salvation Farms 2015 annual report. Retrieved from http:// www.salvationfarms.org/ aboutus.html\#finance

Snow, T., \& D ean, E. (2016). Food loss in V ermont: E stimating annual vegetable \& berry loss. A salvation farms' analysis. Retrieved from http:// salvationfarms.org/VT Food Loss Study 2016.pdf

Spiker, M. L., Hiza, H., Siddiqi, S., \& Neff, R. A. (2017). Wasted food, wasted nutrients: Nutrient loss from wasted food in the US and comparison to gaps in dietary intake. Journal of the A cademy of $\mathrm{N}$ utrition and D ietetics, 117(7), 1031-1040. https:// doi.org/ 10.1016/j.jand.2017.03.015

U.S. D epartment of Health and Human Services, \& U.S. D epartment of Agriculture. (2015). 2015-2020 D ietary G uidelines for A mericans. Retrieved from https:/ / health.gov/ DietaryG uidelines/

United Nations [U.N.]. (2015). C entral Product Classification (CPC). New York: United Nations.

U.N., D epartment of Economic and Social Affairs, \& Statistics Division. (2008). International standard industrial classification of all economic activities. Retrieved from https:/ / unstats.un.org/ unsd/ publication/ seriesM/ seriesm 4rev4e.pdf

U.S. D epartment of Agriculture [USD A], Agricultural Research Service, Nutrient D ata Laboratory. (2015, O ctober). U SD A N ational N utrient D atabase for Standard R eferenœ D ataset for W hat W e E at In A merica, N H A N E S (Survey-SR). Retrieved from https:// www.ars.usda.gov/ northeast-area/ beltsville-md-bhnrc/ beltsville-human-nutrition-researchcenter/ nutrient-data-laboratory/ docs/ usda-national-nutrient-database-for-standard-reference-dataset-for-what-weeat-in-america-nhanes-survey-sr/

USD A National Agricultural Statistics Service [USD A NASS]. (2012a). 2012 C ensus of agriaulture, V olume 1, Chapter 1: State level data-V ermont. Retrieved from https:/ / www.agcensus.usda.gov/ Publications/ 2012/ Full Report/ Volume 1, Chapter 1 State Level/Vermont/

USD A NASS. (2012b). 2012 Census of agriaulture, V olume 1, Chapter 2: County level data-V ermont. Retrieved from https:// www.agcensus.usda.gov/ Publications/2012/ Full_Report/Volume 1,_Chapter_2_County_Level/ Vermont/

U.S. Environmental Protection Agency [U.S. EPA]. (n.d.-a). U nited States 2030 food loss and waste reduction goal. Retrieved A pril 25, 2018, from https:/ / www.epa.gov/ sustainable-management-food/ united-states-2030-food-loss-and-wastereduction-goal

U.S. EPA. (n.d.-b). Sustainable management of food: Food recovery hierarchy. Retrieved from https:/ / www.epa.gov/ sustainablemanagement-food/food-recovery-hierarchy

Vermont Foodbank. (n.d.). G leaning. Retrieved from https:/ / www.vtfoodbank.org/ gather-food/ gleaning

World Resources Institute. (2016). F ood loss and waste accounting and reporting standard. Retrieved from http:/ / www.flwprotocol.org/ 
Journal of Agriculture, Food Systems, and Community D evelopment ISSN: 2152-0801 online https:/ / www.foodsystemsjournal.org

Appendix A. Survey Instrument (following pages) 


\section{Default Question Block}

\section{Thank you for taking part in Salvation Farms' Vermont Food Loss Survey!}

If you complete Part One of this survey, you will be entered into a raffle to win a $\$ 100$ gift certificate to a location of your choosing. Part One will take you no more than $\mathbf{5}$ minutes to complete.

At the end of Part One, we will ask you if you want to continue on to answer Part Two of this survey, where you would then be eligible to win a $\mathbf{\$ 0 0}$ gift certificate to a location of your choosing. Part Two will take you no more than $\mathbf{1 0}$ minutes to complete.

Before starting, we want to remind you that all information provided in this survey will remain confidential. Only aggregated responses will be reported.

\section{Part One}

What is the name of your farm?

What county is your farm located in?

In 2015, what types of produce did you grow?

Please select all that apply

\section{Vegetables}

Fruits, Berries, \& Tree Nuts 
In 2015 , how many types of vegetables did you grow?

\begin{tabular}{|l|l|lllllllll|l|} 
& 0 & 10 & 20 & 30 & 40 & 50 & 60 & 70 & 80 & 90 & 100 \\
\hline Types of vegetables & & & & & & & & & & & \\
\hline
\end{tabular}

In 2015, how many acres of vegetables did you plant?

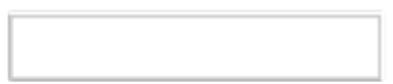

Of the $\$\{q: / / Q I D 227 / C h o i c e T e x t E n t r y V a l u e\}$ acres of vegetables that you planted, how many acres did you harvest?

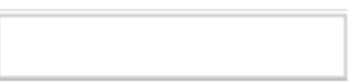

What percent of the vegetables that grew on those $\$\{q: / / Q I D 228 / C h o i c e T e x t E n t r y V a l u e\}$ acres did you harvest?

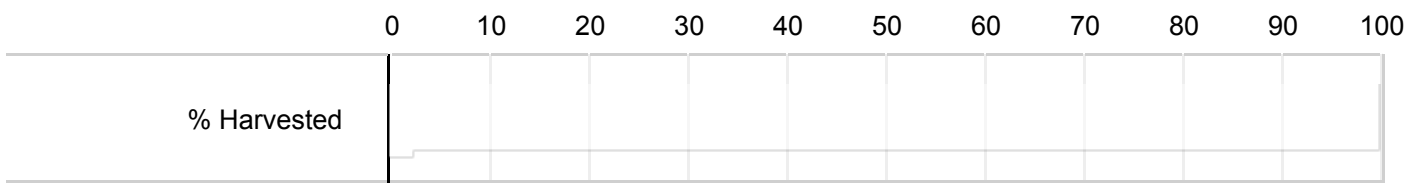

What percent of the vegetables left in the field (i.e. that you did not harvest) were edible?

\begin{tabular}{r|l|lllllllll|l|} 
& 0 & 10 & 20 & 30 & 40 & 50 & 60 & 70 & 80 & 90 & 100 \\
\hline \% Edible & & & & & & & & & & \\
\hline
\end{tabular}


What percent of the vegetables that you harvested did you sell?

\begin{tabular}{|l|l|lllllllll|l|l|} 
& 0 & 10 & 20 & 30 & 40 & 50 & 60 & 70 & 80 & 90 & 100 \\
\hline \% Sold & & & & & & & & & & \\
\hline
\end{tabular}

What percent of the vegetables that you did not sell did you donate?

\begin{tabular}{|l|llllllllll|l|} 
& 0 & 10 & 20 & 30 & 40 & 50 & 60 & 70 & 80 & 90 & 100 \\
\hline \% Donated & & & & & & & & & & \\
\hline
\end{tabular}

In 2015 , how many types of fruits, berries, and nuts did you grow?

\begin{tabular}{|c|c|c|c|c|c|c|c|c|c|c|c|}
\hline & & 2 & 4 & 6 & & & 12 & 14 & 16 & 18 & $\begin{array}{l}\text { Not } \\
\text { Applicable } \\
20\end{array}$ \\
\hline & 0 & 2 & 4 & 6 & 8 & 10 & 12 & 14 & 16 & 18 & 20 \\
\hline $\begin{array}{r}\text { Types of fruits, berries, } \\
\text { nuts }\end{array}$ & & & & & & & & & & & $\square$ \\
\hline & & & & & & & & & & & \\
\hline
\end{tabular}

In 2015 , how many acres of mature fruit trees, berry bushes, and nut trees did you have? 
What percent of the fruits, berries, and nuts that grew did you harvest?

\begin{tabular}{|l|l|llllllll|l|l|} 
& 0 & 10 & 20 & 30 & 40 & 50 & 60 & 70 & 80 & 90 & 100 \\
\hline$\%$ Harvested & & & & & & & & & & \\
\hline
\end{tabular}

Of the fruits, berries, and nuts left on the trees/bushes (i.e. unpicked), what percent were edible?

\begin{tabular}{|l|llllllllll|l|} 
& 0 & 10 & 20 & 30 & 40 & 50 & 60 & 70 & 80 & 90 & 100 \\
\hline & & & & & & & & & & \\
\hline
\end{tabular}

What percent of the fruits, berries, and nuts that you harvested did you sell?

\begin{tabular}{r|lllllllllll|} 
& 0 & 10 & 20 & 30 & 40 & 50 & 60 & 70 & 80 & 90 & 100 \\
\hline & & & & & & & & & & & \\
\hline
\end{tabular}

What percent of the fruits, berries, and nuts that you did not sell did you donate?

\begin{tabular}{|l|l|llllllll|l|l|l|} 
& 0 & 10 & 20 & 30 & 40 & 50 & 60 & 70 & 80 & 90 & 100 \\
\hline \% Donated & & & & & & & & & & & \\
\hline
\end{tabular}


Thank you for completing Part One of this survey. You have been entered into a raffle to win a $\$ 100$ gift certificate.

If you continue onto Part Two of this survey, you will be entered into a raffle to win a $\$ \mathbf{3 0 0} \mathbf{g i f t}$ certificate to a location of your choosing. Part Two will take you no more than $\mathbf{1 0}$ minutes to complete.

I would like to continue to Part Two

I would like to end

\section{Part Two}

What were the reasons you did not harvest some of your produce?

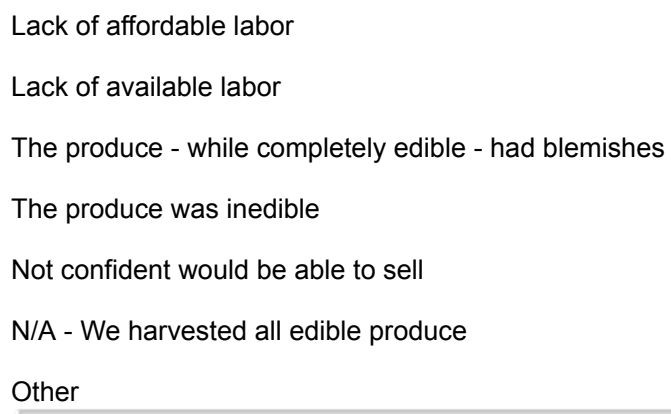

What happened to the crops that you did not harvest?

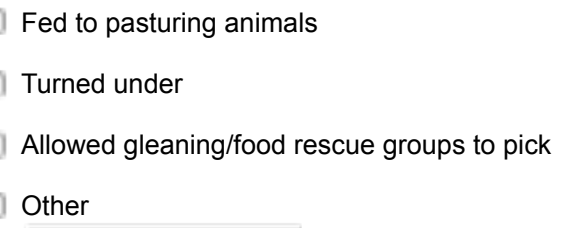


How much of your produce did you lose during the following stages?

\begin{tabular}{l|ccccc} 
& None & Very little & $\begin{array}{c}\text { A moderate } \\
\text { amount }\end{array}$ & A lot & N/A \\
\hline Washing \& Packing & 0 & 0 & 0 & 0 & 0 \\
Storing & 0 & 0 & 0 & 0 & 0 \\
Transporting & 0 & 0 & 0 & 0 & 0 \\
At market & 0 & 0 & 0 & 0 & 0
\end{tabular}

What were the reasons that you were not able to sell some of your produce?

General lack of demand for the item

Oversaturation of the market with the item

The produce - while completely edible - had blemishes

The produce was only partially edible

Other

What happened to the produce that you did not sell?

Fed to animals

Used for compost

Eaten by farmers

Donated to community groups

$\square$ Other 
What were three of your main crops in $2015 ?$

i.e. Kale, Sweet Potatoes, Corn

Crop 1 Name
Crop 2 Name
Crop 3 Name

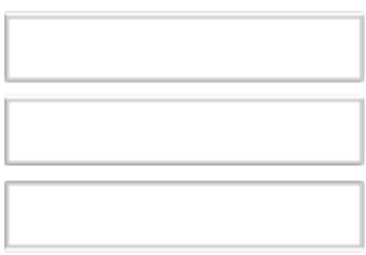

In 2015 , how many acres did you plant?

\begin{tabular}{|c|c|}
\hline 0 & Acres of $»$ Crop 1 Name \\
\hline 0 & Acres of $»$ Crop 2 Name \\
\hline 0 & Acres of ॥ Crop 3 Name \\
\hline
\end{tabular}

In 2015 , how many acres did you harvest?

\begin{tabular}{|l|l|}
\hline 0 & Acres Harvested of ॥ Crop 1 Name \\
\hline 0 & Acres Harvested of ॥ Crop 2 Name \\
\hline 0 & Acres Harvested of ॥ Crop 3 Name \\
\hline
\end{tabular}

What percent of each crop did you harvest?

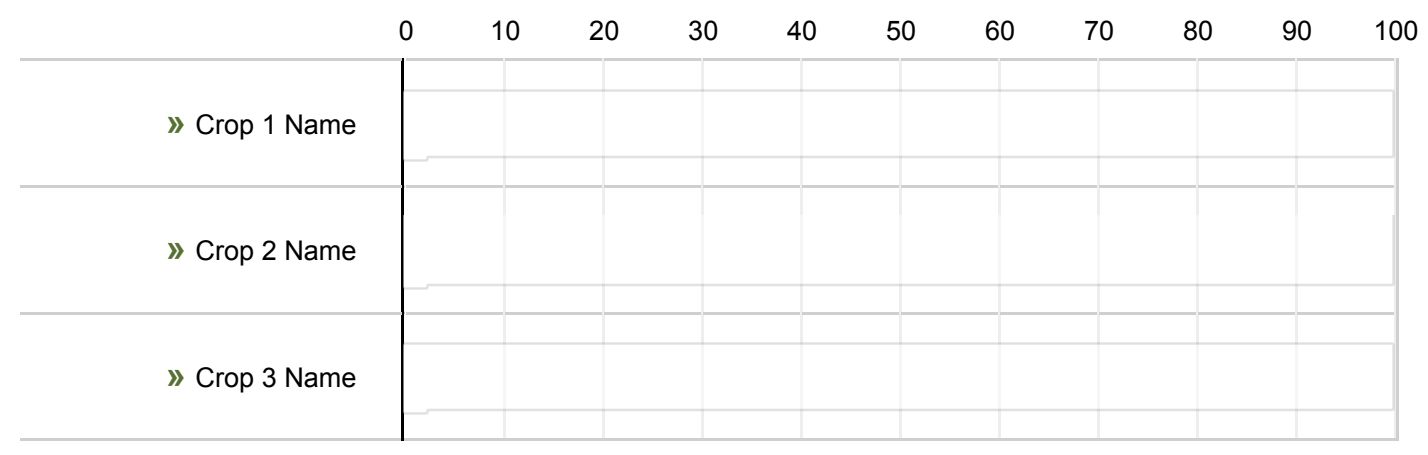


What percent of what you harvested were you able to sell?

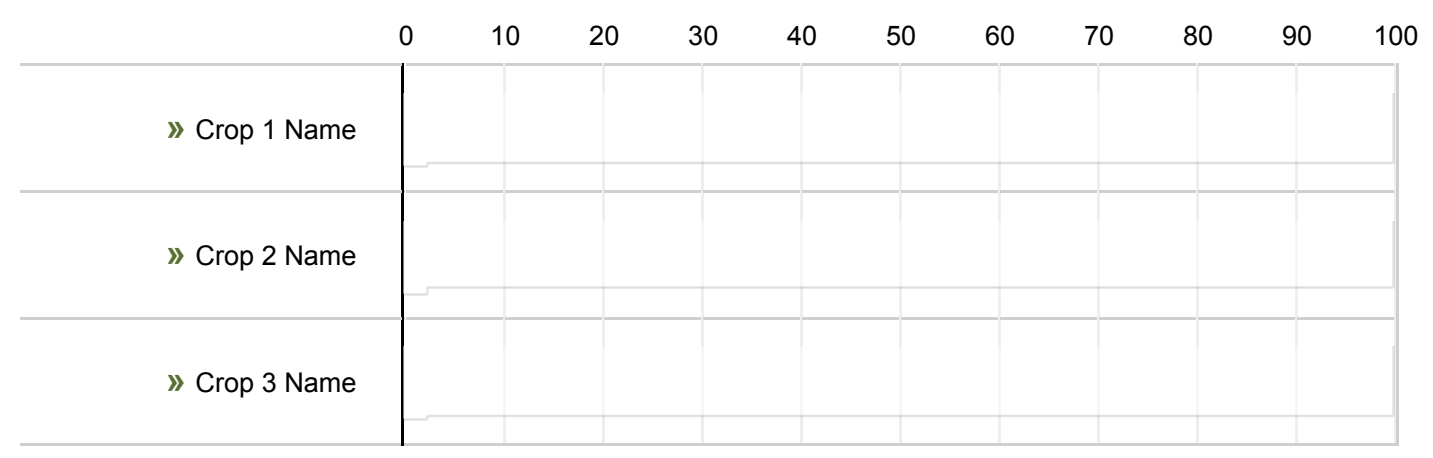

What percent of what you left unharvested (i.e. in the field or on the trees) was edible?

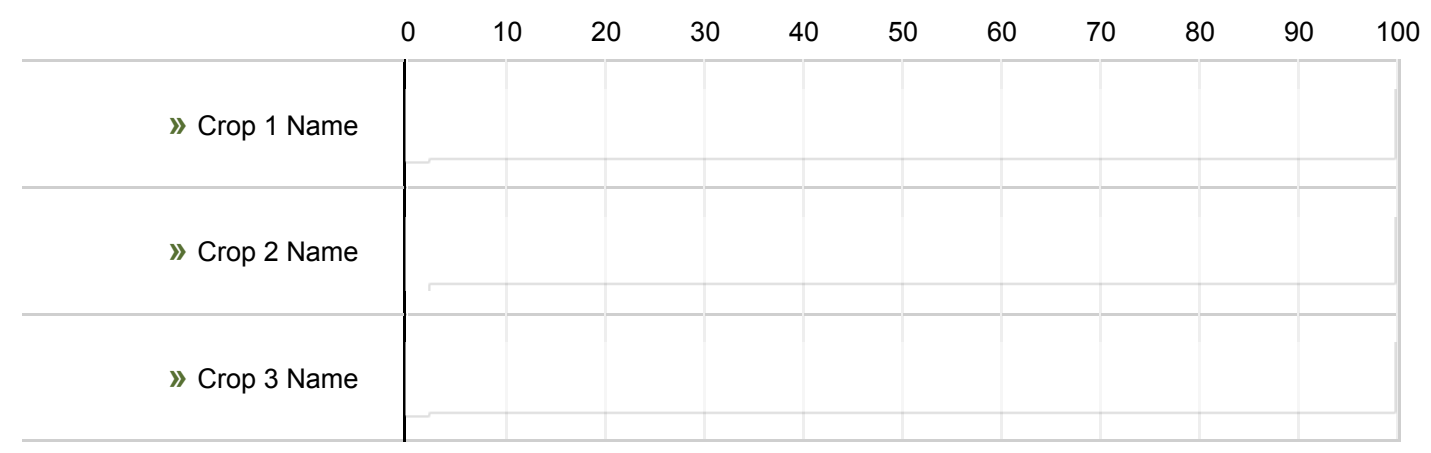

In 2015, where did you sell your produce?

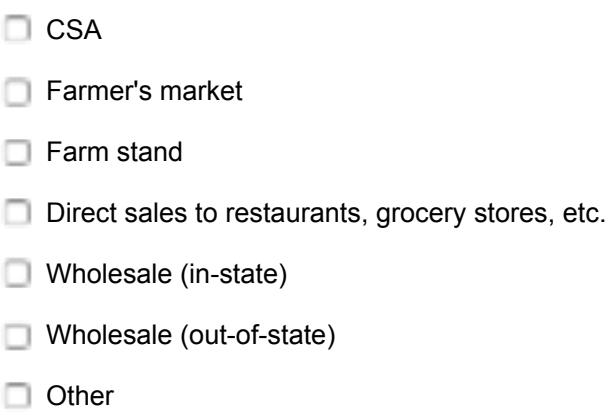


Do you keep an inventory of produce sold through your CSA?

Yes, for all crops

Yes, for some crops

No

Do you keep an inventory of produce sold at farm stands?

Yes, for all crops

Yes, for some crops

No

Do you keep an inventory of produce sold at the farmer's markets?

Yes, for all crops

Yes, for some crops

No

Do you keep invoices for produce sold in direct sales?

Yes, for all crops

Yes, for some crops

No

Do you keep invoices for produce sold to wholesale markets?
Yes, for all crops
Yes, for some crops
No 
Do you keep a physical record of what you plant and/or harvest each year?

(This is sometimes referred to as a "crop record" or "crop log")

Yes, for all crops

Yes, for some crops

No

Which of the following do you record?

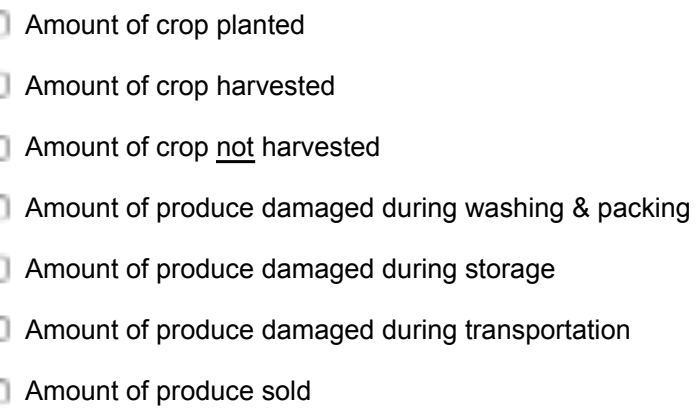

Where do you record the following information?

\begin{tabular}{l|ccc} 
& On Paper & On Computer & On Smartphone App N/A \\
\hline " Amount of crop planted & $\square$ & $\square$ & $\square$ \\
" Amount of crop harvested & $\square$ & $\square$ & $\square$ \\
" Amount of crop not harvested & $\square$ & $\square$ & $\square$ \\
" Amount of produce damaged & $\square$ & $\square$ & $\square$ \\
during washing \& packing & $\square$ & $\square$ & $\square$ \\
" Amount of produce damaged & & $\square$ \\
during storage & & $\square$ \\
" Amount of produce damaged & & $\square$ & $\square$ \\
" Aming transportation & $\square$ & $\square$
\end{tabular}

What is the name of the tracking system that you used (if there is one)? 
In 2015 , what services did community groups provide to your farm?

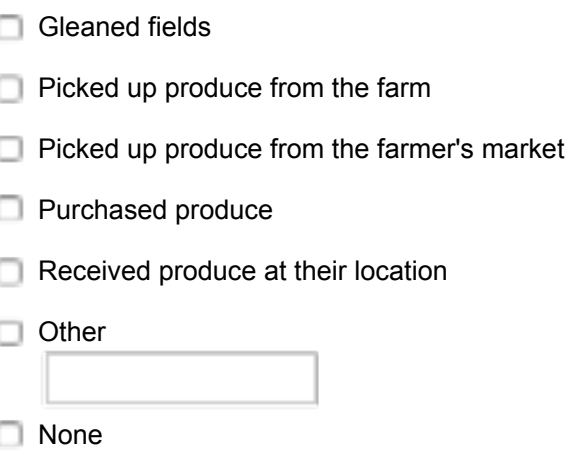

How would you rate the community groups you worked with in $2015 ?$

\author{
Overall communication \\ Overall service \\ Management of volunteer crews \\ Consistency of service \\ Showing up when scheduled \\ Responsiveness to farmer needs \\ Responsiveness to farmer \\ instructions \\ Respect for farm operations \\ Respect for farmer's time
}


What services would you like community groups to provide to your farm this coming year?

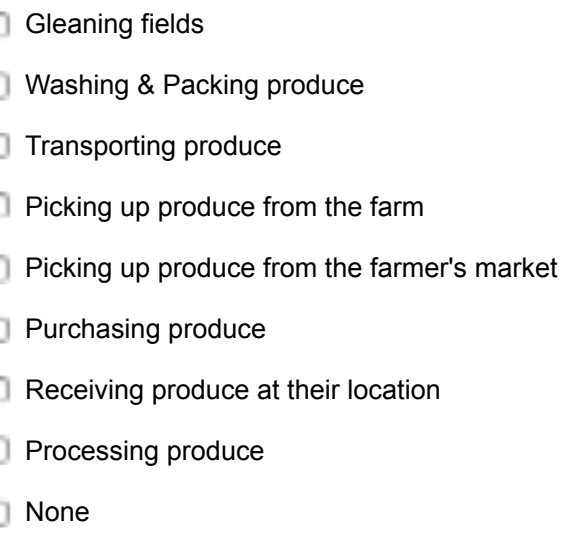

Did you claim any federal tax deductions for food donations that you made in $2015 ?$

$\square$ Yes

$\square$ No

Not sure

Are you planning on claiming a federal tax deduction for food donations that you will make in $2016 ?$
Definitely yes
Probably yes
Might or might not
Probably not
Definitely not 
Would you be interested in the state of Vermont providing financial compensation to farmers for their food donations?
Definitely yes
Probably yes
Might or might not
Probably not
Definitely not 


\section{Appendix B. Vegetables and Berries Grown on Farms in Survey Sample}

Survey part 2 respondents were asked the open-ended question, "What were three of your main crops in 2015?" Forty-eight farms listed three crops, two provided two crops, and three provided one. If the row for the item type (bold) has a number, e.g., brassica, it means some respondents listed the category rather than a specific item.

\begin{tabular}{lc}
\hline ITEM & \# Farms \\
\hline Berries & \\
\hline Apples & 2 \\
Blueberries & 5 \\
Plums & 1 \\
Quince & 1 \\
Raspberries & 3 \\
Strawberries & 6 \\
\hline Brassica & 1 \\
\hline Broccoli & 1 \\
Brussels sprouts & 1 \\
Cabbage & 4 \\
\hline Greens & 5 \\
\hline Dandelion greens & 1 \\
Kale & 7 \\
Lettuce/ salad greens/mesclun [multiple types] & 17 \\
Swiss chard & 1 \\
Tatsoi & 1 \\
\hline Herbs & 1 \\
\hline Parsley & 1 \\
\hline Roots, other than potato & \\
\hline Beets & 5 \\
Carrot & 5 \\
Celeriac & 1 \\
Garlic & 8 \\
Onions & 4 \\
Roots & 1 \\
Sweet potato & 1 \\
\hline
\end{tabular}

\begin{tabular}{lr}
\hline ITEM & \# Farms \\
\hline Solanaceae & \\
\hline Eggplant & 1 \\
Peppers & 5 \\
Potato & 11 \\
Tomatillos & 1 \\
Tomatoes & 18 \\
\hline Squash & \\
\hline Buttercup squash & 1 \\
Pumpkin & 2 \\
Winter squash & 5 \\
\hline Other & \\
\hline Asparagus & 1 \\
Beans & 4 \\
Corn & 6 \\
Cucumbers & 4 \\
Peas & 1 \\
\hline
\end{tabular}




\section{Appendix B. Vegetables and Berries Grown on Farms in Survey Sample}

Survey part 2 respondents were asked the open-ended question, "What were three of your main crops in 2015?" Forty-eight farms listed three crops, two provided two crops, and three provided one. If the row for the item type (bold) has a number, e.g., brassica, it means some respondents listed the category rather than a specific item.

\begin{tabular}{lc}
\hline ITEM & \# Farms \\
\hline Berries & \\
\hline Apples & 2 \\
Blueberries & 5 \\
Plums & 1 \\
Quince & 1 \\
Raspberries & 3 \\
Strawberries & 6 \\
\hline Brassica & 1 \\
\hline Broccoli & 1 \\
Brussels sprouts & 1 \\
Cabbage & 4 \\
\hline Greens & 5 \\
\hline Dandelion greens & 1 \\
Kale & 7 \\
Lettuce/ salad greens/mesclun [multiple types] & 17 \\
Swiss chard & 1 \\
Tatsoi & 1 \\
\hline Herbs & 1 \\
\hline Parsley & 1 \\
\hline Roots, other than potato & \\
\hline Beets & 5 \\
Carrot & 5 \\
Celeriac & 1 \\
Garlic & 8 \\
Onions & 4 \\
Roots & 1 \\
Sweet potato & 1 \\
\hline
\end{tabular}

\begin{tabular}{lr}
\hline ITEM & \#Farms \\
\hline Solanaceae & \\
\hline Eggplant & 1 \\
Peppers & 5 \\
Potato & 11 \\
Tomatillos & 1 \\
Tomatoes & 18 \\
\hline Squash & \\
\hline Buttercup squash & 1 \\
Pumpkin & 2 \\
Winter squash & 5 \\
\hline Other & \\
\hline Asparagus & 1 \\
Beans & 4 \\
Corn & 6 \\
Cucumbers & 4 \\
Peas & 1 \\
\hline
\end{tabular}


Journal of Agriculture, Food Systems, and Community D evelopment

ISSN: 2152-0801 online

https:/ / www.foodsystemsjournal.org

\section{Appendix C.}

Table C1. Statewide Estimates Weighted by Farm Size

\begin{tabular}{|c|c|c|c|c|}
\hline & $\begin{array}{c}\text { Farms Producing } \\
\text { Vegetables, } n=53 \text { : } \\
\text { WEIGHTED }\end{array}$ & $\begin{array}{c}\text { Farms Producing } \\
\text { Vegetables, } n=53 \text { : } \\
\text { Unweighted }\end{array}$ & $\begin{array}{c}\text { Farms Producing } \\
\text { Berries, } n=26: \\
\text { WEIGHTED }\end{array}$ & $\begin{array}{l}\text { Farms Producing } \\
\text { Berries, } n=26: \\
\text { Unweighted }\end{array}$ \\
\hline Total farm acreage & \multicolumn{2}{|c|}{3,897} & \multicolumn{2}{|c|}{601} \\
\hline Yield fraction applied & \multicolumn{2}{|c|}{$0.5 \mathrm{lb} / \mathrm{ft}^{2}$} & \multicolumn{2}{|c|}{$0.15 \mathrm{lb} / \mathrm{ft}^{2}$} \\
\hline Total quantity available for harvest (lb.) & \multicolumn{2}{|c|}{$84,876,660$} & \multicolumn{2}{|c|}{$3,926,934$} \\
\hline \% Harvested & 87.9 & 84.7 & 90.9 & 85 \\
\hline \% Sold & 78.0 & 80.7 & 90.4 & 86.2 \\
\hline \% Donated of Unsold & 32.4 & 33.2 & 1.6 & 3.8 \\
\hline \% Edible of Unharvested & 30.7 & 34 & 23.0 & 24.7 \\
\hline Harvested (lb.) & $74,609,021$ & $71,890,531$ & $3,571,154$ & $3,337,894$ \\
\hline Sold (Ib.) & $58,196,002$ & $58,015,659$ & $3,228,680$ & $2,877,265$ \\
\hline Donated (lb.) & $5,312,241$ & $4,606,458$ & 5,542 & 17,504 \\
\hline Not sold, not donated (lb.) & $11,100,778$ & $9,268,415$ & 336,931 & 443,125 \\
\hline Not harvested (lb.) & $10,267,639$ & $12,986,129$ & 355,780 & 589,040 \\
\hline Not harvested but edible (lb.) & $3,155,387$ & $4,415,284$ & 81,918 & 145,493 \\
\hline Salvageable loss (lb.) & $14,256,166$ & $13,683,699$ & 418,850 & 588,618 \\
\hline $\begin{array}{l}\% \text { of available harvest that was } \\
\text { salvageable loss }\end{array}$ & $16.8 \%$ & $16.1 \%$ & $10.7 \%$ & $15.0 \%$ \\
\hline
\end{tabular}

Note: $1 \mathrm{lb} .=0.45 \mathrm{~kg}$.

Table C2. Weighting Calculation

\begin{tabular}{|c|c|c|c|c|c|c|c|c|}
\hline & \multicolumn{4}{|c|}{ Vegetables } & \multicolumn{4}{|c|}{ Berries } \\
\hline & $\begin{array}{l}.1-4.9 \\
\text { Acres }\end{array}$ & $\begin{array}{c}\text { 5-24.9 } \\
\text { Acres }\end{array}$ & $\begin{array}{c}25-99 \\
\text { Acres }\end{array}$ & $\begin{array}{l}100 \text { Acres } \\
\text { and Larger }\end{array}$ & & $\begin{array}{l}.1-4.9 \\
\text { Acres }\end{array}$ & $\begin{array}{l}5 \text { Acres and } \\
\text { Larger }\end{array}$ & \\
\hline Percent Harvested & 88.8 & 78.8 & 78.8 & 90.5 & & 88.5 & 98.7 & \\
\hline Percent Sold & 75.0 & 85.2 & 92.2 & 95.0 & & 90.8 & 89.3 & \\
\hline Percent Donated of Unsold & 31.0 & 38.1 & 31.6 & 25.0 & & 1.7 & 1.3 & \\
\hline Percent Edible of Unharvested & 27.7 & 43.5 & 38.4 & 32.5 & & 29.9 & 1.3 & \\
\hline \multirow[t]{2}{*}{$\%$ Farms in State } & 0.82 & 0.15 & 0.03 & 0.01 & & 0.76 & 0.24 & \\
\hline & 0.3 & 0.2 & 0.1 & 0.1 & & 0.1 & 0.1 & \\
\hline Weighted means & & & & & $\begin{array}{c}\text { Sum of } \\
\text { Vegetables }\end{array}$ & & & $\begin{array}{l}\text { Sum of } \\
\text { Berries }\end{array}$ \\
\hline Percent Harvested & 72.8 & 11.8 & 2.4 & 0.9 & 87.9 & 67.3 & 23.7 & 90.9 \\
\hline Percent Sold & 61.5 & 12.8 & 2.8 & 1.0 & 78.0 & 69.0 & 21.4 & 90.4 \\
\hline Percent Donated of Unsold & 25.5 & 5.7 & 0.9 & 0.3 & 32.4 & 1.3 & 0.3 & 1.6 \\
\hline \multirow[t]{2}{*}{ Percent Edible of Unharvested } & 22.7 & 6.5 & 1.2 & 0.3 & 30.7 & 22.7 & 0.3 & 23.0 \\
\hline & 11.31 & -0.96 & 0.98 & 0.99 & 12.3 & 0.31 & 0.79 & 1.1 \\
\hline
\end{tabular}

Note: 1 acre $=0.4$ ha 


\section{Appendix D. Sensitivity Analysis Summary}

\begin{tabular}{l|r|r|r|r} 
& Vegetables & Fruits & Vegetables + Fruits & $\begin{array}{c}\text { All (Vegetables only; } \\
\text { fruits only; } \\
\text { vegetables +fruits) }\end{array}$ \\
\hline Original Estimates & $13,683,699$ & 589,000 & $14,272,699$ & \\
\hline 1. Weighting by farm size & $14,256,166$ & 418,850 & & \\
\hline Difference from original & $+572,467$ & $-170,150$ & & \\
\hline 2. Gleaning & & & $13,655,003$ & \\
\hline Difference from original & & & $-617,696$ & \\
\hline 3. Home consumption & & 563,056 & & \\
\hline Difference from original & & $-34,086$ & & \\
\hline 4. Alternative yield fraction & $12,041,655$ & & & \\
\hline Difference from original & $1,642,044$ & & & \\
\hline $\begin{array}{l}\text { SUM of differences from original- } \\
\text { all sensitivity analyses }\end{array}$ & $-1,069,577$ & $-204,236$ & $-617,696$ & $1,891,509$ \\
\hline $\begin{array}{l}\text { New estimate incorporating all } \\
\text { sensitivity analyses }\end{array}$ & & & & $12,381,190$ \\
\hline$\%$ Change & & & & \\
\hline
\end{tabular}

